\title{
Physicochemical characteristics and occupational exposure to coarse, fine and ultrafine particles during building refurbishment activities
}

\author{
Farhad Azarmi ${ }^{a}$, Prashant Kumara, b,*, Mike Mulherona, Julien L. Colaux ${ }^{c}$, Chris \\ Jeynes $^{c}$, Siavash Adhami d, John F Watts ${ }^{\mathrm{d}}$
}

aDepartment of Civil and Environmental Engineering, Faculty of Engineering and Physical Sciences, University of Surrey, Guildford GU2 7XH, United Kingdom

benvironmental Flow (EnFlo) Research Centre, Faculty of Engineering and Physical Sciences, University of Surrey, Guildford GU2 7XH, United Kingdom

'Ion Beam Centre, Faculty of Engineering and Physical Sciences, University of Surrey, Guildford GU2 7XH, United Kingdom

dThe Surface Analysis Laboratory, Faculty of Engineering and Physical Sciences, University of Surrey, Guildford, GU2 7XH, United Kingdom

\footnotetext{
*Corresponding author: Department of Civil and Environmental Engineering, Faculty of Engineering and Physical Sciences, University of Surrey, Guildford GU2 7XH, United Kingdom; Tel.: +44 1483 682762; Fax: +44 1483 682135; E-mail addresses: P.Kumar@surrey.ac.uk, Prashant.Kumar@cantab.net
}

Cite this article as: Azarmi, F., Kumar, P., Mulheron, M., Colauxc, J.L., Jeynes, C., Adhami, S., Watts, J.F., 2015. Physicochemical characteristics and occupational exposure to coarse, fine and nanoparticle emissions during building refurbishment activities, Journal of Nanoparticle Research 17, 343, doi: 10.1007/s11051-015-3141-z. Online link: http://dx.doi.org/10.1007/s11051-015-3141-z 


\section{Graphical abstract}

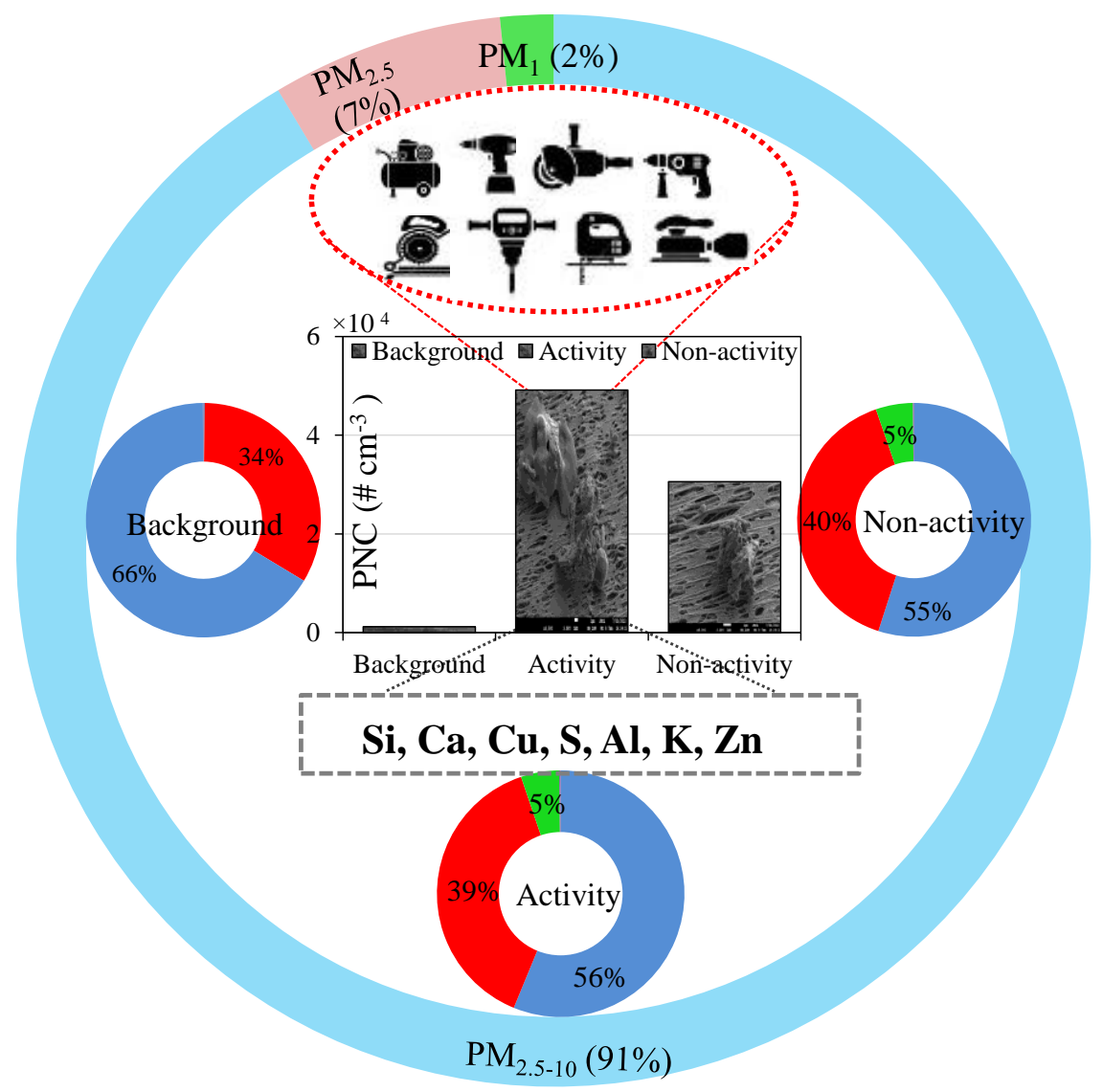

\section{ABSTRACT}

Understanding of the emissions of coarse ( $\left.\mathrm{PM}_{10} \leq 10 \mu \mathrm{m}\right)$, fine $\left(\mathrm{PM}_{2.5} \leq 2.5 \mu \mathrm{m}\right)$ and ultrafine particles (UFP $<100 \mathrm{~nm}$ ) from refurbishment activities and their dispersion into the nearby environment is of primary importance for developing efficient risk assessment and management strategies in the construction and demolition industry. This study investigates the release, occupational exposure and physicochemical properties of particulate matter, including UFPs, from over 20 different refurbishment activities occurring at an operational building site. Particles were measured in the $5-10,000 \mathrm{~nm}$ size range using a fast response differential mobility spectrometer and a GRIMM particle spectrometer for 55 hours over 8 days. The UFPs were found to account for $>90 \%$ of the total particle number

Cite this article as: Azarmi, F., Kumar, P., Mulheron, M., Colauxc, J.L., Jeynes, C., Adhami, S., Watts, J.F., 2015. Physicochemical characteristics and occupational exposure to coarse, fine and nanoparticle emissions during building refurbishment activities, Journal of Nanoparticle Research 17, 343, doi: 10.1007/s11051-015-3141-z. Online link: http://dx.doi.org/10.1007/s11051-015-3141-z 
concentrations and $<10 \%$ of the total mass concentrations released during the recorded activities. The highest UFP concentrations were 4860, 740, 650 and 500 times above the background value during wall chasing, drilling, cementing and general demolition activities, respectively. Scanning electron microscopy, X-ray photoelectron spectroscopy and ion beam analysis were used to identify physicochemical characteristics of particles and attribute them to probable sources considering the size and the nature of the particles. The results confirm that refurbishment activities produce significant levels (both number and mass) of airborne particles, indicating a need to develop appropriate regulations for the control of occupational exposure of operatives undertaking building refurbishment.

Key words: Building refurbishment; Particulate matter; Ultrafine particles; SEM, XPS and IBA; Occupational exposure

\section{INTRODUCTION}

The principles of sustainable urban development are well established, but the extent of pollution due to refurbishment activities is still unknown. The aim of building refurbishment is typically to adapt the existing space to meet the needs and expectations of occupants and bring older buildings up to modern standards for heating, lighting and energy efficiency, as well as to give outdated buildings an upgrading and redesign that goes beyond the cosmetic. The drive for sustainable refurbishment includes both the provision of improved lighting, insulation, ventilation and facilities to ensure the comfort and needs of users as well as related measures to reduce energy consumption in buildings (Mickaityte et al., 2008; Omer, 2008; Sunikka and Boon, 2003).

Within many existing urban environments, refurbishment has become a major, and increasingly important, activity and it is predicted to become the dominant construction activity in the years ahead (Sartori et al., 2008). Due to the increase in rate of population within urban areas (Egbu, 1999; Kumar et al., 2013a), activities related to refurbishment of the building stock as a percentage of all building work have already grown in most European countries over the last 20 years (Kohler and Cite this article as: Azarmi, F., Kumar, P., Mulheron, M., Colauxc, J.L., Jeynes, C., Adhami, S., Watts, J.F., 2015. Physicochemical characteristics and occupational exposure to coarse, fine and nanoparticle emissions during building refurbishment activities, Journal of Nanoparticle Research 17, 343, doi: 10.1007/s11051-015-3141-z. Online link: http://dx.doi.org/10.1007/s11051-015-3141-z 
Hassler, 2002). Refurbishment activities are expected to grow further as more than $60 \%$ of the world's population are likely to be living in urban areas by 2035 (GroBmann et al., 2013). Such long-term changes in building demand within Europe will constrain the building professions to shift their focus from new construction to the maintenance and refurbishment of existing buildings (Kohler and Hassler, 2002).

In recognition of changes in the age of structure and population rate within urban environments, significant sectors of the construction industry have concentrated on developing innovative refurbishment techniques. However, the various demolition and construction activities associated with building refurbishment are known to produce copious particulate matter $(\mathrm{PM})$, including coarse $\left(\mathrm{PM}_{10} \leq 10 \mu \mathrm{m}\right)$, fine $\left(\mathrm{PM}_{2.5} \leq 2.5 \mu \mathrm{m}\right)$, very fine $\left(\mathrm{PM}_{1} \leq 1 \mu \mathrm{m}\right)$ and ultrafine particles (UFP $<100 \mathrm{~nm}$ ) (Kumar et al., 2012b; 2013b). PM has serious environmental and health-related consequences because it contains a wide variety of toxic organic and metallic compounds (Heal et al., 2012). Urban dust, particularly $\mathrm{PM}_{10}$, is harmful since it can be easily introduced in the respiratory system (Davila et al., 2006), although there is increasing interest in $\mathrm{PM}_{2.5}$ and UFPs since these penetrate deeper into the lungs and are thought to be of greater concern for human health (Chaloulakou et al., 2003). In fact, $\mathrm{PM}_{2.5}$ has been recognised as $9^{\text {th }}$ powerful risk factor globally for burden of disease (Lim et al., 2012). Building activities produce both airborne dust (Batonneau et al., 2004) and the emissions of UFPs (Azarmi et al., 2014; Kumar and Morawska, 2014) which are causally involved in greater inflammatory responses than the coarse particles per given mass (HEI, 2013; Kumar et al., 2014). Refurbishment activities are important part of building construction since these can have an associated carbon footprint of the order of $20 \%$ of the emissions that arise from the original construction (Pacca and Horvath, 2002). Therefore, the development of efficient monitoring strategies to study the concentration and distribution of urban particles can help in mitigating the effects of urban pollution on public health. As a consequence, it is essential to determine the exposure levels of operatives involved in building refurbishment as well as understanding the Cite this article as: Azarmi, F., Kumar, P., Mulheron, M., Colauxc, J.L., Jeynes, C., Adhami, S., Watts, J.F., 2015. Physicochemical characteristics and occupational exposure to coarse, fine and nanoparticle emissions during building refurbishment activities, Journal of Nanoparticle Research 17, 343, doi: 10.1007/s11051-015-3141-z. Online link: http://dx.doi.org/10.1007/s11051-015-3141-z 
distribution and propagation of particulate materials into the surrounding environment. .

It has now been established that various size of particles arising from vehicle exhaust and non-vehicle exhaust sources enhance their concentrations in certain areas (Dall'Osto et al., 2011; Hopke et al., 1980; Kumar and Morawska, 2014; Kumar et al., 2010, 2011b, 2013b). A few studies have also reported the particle number and mass emissions arising from the demolition of buildings and transport structures (Dorevitch et al., 2006; Hansen et al., 2008), concrete recycling (Kumar and Morawska, 2014) and road works (Fuller et al., 2002; Fuller and Green, 2004). Several studies have also analysed the composition of particles derived from such sources and a number of attempts have been made to relate the observed elemental concentrations in collected particle samples to such activities (Adachi and Tainosho, 2004; Adhami et al., 2012; Adhami et al., 2014; Batonneau et al., 2004; Chen et al., 2000; Mouzourides et al., 2015; Pattanaik et al., 2012). A few studies have utilised the Scanning Electron Microscope (SEM) for examining the solid-phase of metals and metalloids in house dust (Walker et al., 2011), apportioning the sources of lead in household dust (Hunt et al., 1992) and laser cleaning of building stones (Potgieter-Vermaak et al., 2005). The scanning electron microscopy together with focussed ion beam milling (FIB-SEM) has been used to investigate the composition of atmospheric particles (Conny, 2013). The conjunction of Particle Induced X-ray Emission (PIXE) and Elastic Backscattering Spectrometry (EBS) techniques represent powerful tools for measuring the elemental composition of fine atmospheric particles sampled on filters such as applied by Cohen et al. (1996) to source fingerprinting of atmospheric fine particles. Despite these studies there remains a considerable research gap with respect to the presence of elements such as Arsenic (As), Cadmium (Cd), Chromium (Cr), Lead (Pb), Manganese (Mn), Nickel (Ni) and Zinc (Zn) within the particles arising from refurbishment activities.

Over the past 35 years, there has been $\sim 20 \%$ increase in refurbishment work in relation to the total volume of UK construction output (Egbu, 1999). This growth

Cite this article as: Azarmi, F., Kumar, P., Mulheron, M., Colauxc, J.L., Jeynes, C., Adhami, S., Watts, J.F., 2015. Physicochemical characteristics and occupational exposure to coarse, fine and nanoparticle emissions during building refurbishment activities, Journal of Nanoparticle Research 17, 343, doi: 10.1007/s11051-015-3141-z. Online link: http://dx.doi.org/10.1007/s11051-015-3141-z 
has, however, not been matched by comparable research in the environmental impacts. In continuation to our prior efforts (Kumar et al., 2012a, b, c; 2013b; Kumar and Morawska, 2014; Azarmi et al., 2014), this study investigates the release of particle number distribution (PNDs) and concentrations (PNCs) in sub-micrometre range, along with particle mass concentrations (PMCs) in $\mathrm{PM}_{10}, \mathrm{PM}_{2.5}$ and $\mathrm{PM}_{1}$ size range, arising from a number of refurbishment activities and associated occupational exposure for construction workers. The characteristics of these particles have also been investigated to help understand their physicochemical nature and the potential impact of associated exposure on operatives undertaking building refurbishment.

\section{MATERIALS AND METHODS}

\subsection{Site description and sampling setup}

Experiments were carried out at an indoor refurbishment site (Chemistry Laboratory) at the University of Surrey that was $31 \mathrm{~m}$ long and $15.5 \mathrm{~m}$ wide (Figure 1) to measure the $\mathrm{PM}_{10}, \mathrm{PM}_{2.5}, \mathrm{PM}_{1}$ and UFP released from refurbishment activities. The data were collected for a total of 55 working hours between 08:00 and 18:00 $\mathrm{h}$ (local time) over a period of 8 days; of which, one day was without any activity that enabled us to evaluate the levels of local background. The refurbishment site had 1 $\mathrm{m}$ wide and $0.32 \mathrm{~m}$ deep windows that were slightly open most of the sampling duration (Figure 1). However, the ambient wind speed during the sampling period was relatively low $\left(<1.5 \mathrm{~m} \mathrm{~s}^{-1}\right)$, giving almost steady dilution conditions at the site during the study period. There were also three door openings towards a main corridor (Figure 1) but these doors were covered with a thick plastic sheet acting as a temporary protection shield for trapping the particles released on the site. Further details of the description of site can be seen in Supplementary Information, SI, Section S1.

Cite this article as: Azarmi, F., Kumar, P., Mulheron, M., Colauxc, J.L., Jeynes, C., Adhami, S., Watts, J.F., 2015. Physicochemical characteristics and occupational exposure to coarse, fine and nanoparticle emissions during building refurbishment activities, Journal of Nanoparticle Research 17, 343, doi: 10.1007/s11051-015-3141-z. Online link: http://dx.doi.org/10.1007/s11051-015-3141-z 


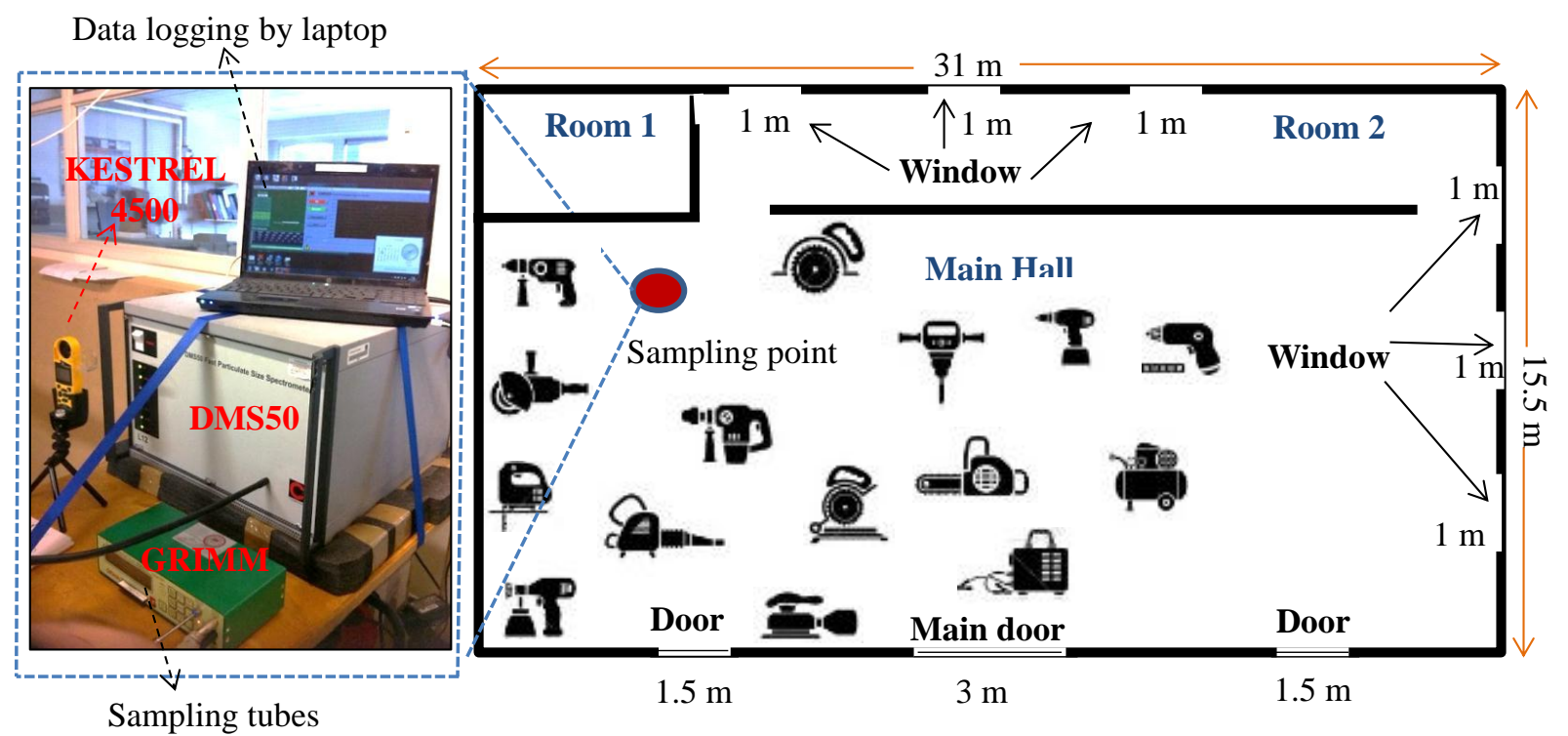

Figure 1. Schematic diagram of the experimental set-up, showing instrumentation used and sampling locations.

An exhaustive list of a number of refurbishment activities performed during the sampling period is presented in SI Table S1. Over 20 different refurbishment activities were counted, including some of the most frequent ones such as general demolition and cutting of concrete, welding, wall chasing, painting, cutting abrasive blasting, hammering, impact driving, sawing and cementing (SI Table S1 and Figure S1). Emitted particles were measured in the 5-10,000 $\mathrm{nm}$ size range using a GRIMM particle spectrometer (model 1.107) and a fast response differential mobility spectrometer (Cambustion DMS50), as described in Section 2.2. The time stamp of both the instruments was set same to local GMT time. The instrument was placed at the closest safe place ( $\sim 2 \mathrm{~m}$ from the closest activity) at the site (Figure 1). Five different samples were also collected on Polytetrafluoroethylene (PTFE) filters by the GRIMM instrument for the purpose of their physicochemical analysis (Section 2.3). These filters collected all the particles above the pore size $(0.12 \mu \mathrm{m})$ of filters.

\subsection{Instrumentation}

The DMS50 was used to measure the size of the particles in the $5-560 \mathrm{~nm}$ size range based on their electrical mobility equivalent diameter with a sampling rate

Cite this article as: Azarmi, F., Kumar, P., Mulheron, M., Colauxc, J.L., Jeynes, C., Adhami, S., Watts, J.F., 2015. Physicochemical characteristics and occupational exposure to coarse, fine and nanoparticle emissions during building refurbishment activities, Journal of Nanoparticle Research 17, 343, doi: 10.1007/s11051-015-3141-z. Online link: http://dx.doi.org/10.1007/s11051-015-3141-z 
of $10 \mathrm{~Hz}$ and a time response ( $\mathrm{T}_{10-90 \%}$ ) of $500 \mathrm{~ms}$ (Al-Dabbous and Kumar, 2014a, b). The instrument sampled the air at a rate of 6.5 lit min $^{-1}$. To improve the signalto-noise ratio, the DMS50 was set to average the samples every 10 sampling points to give a one second sampling rate. This instrument has been successfully used for our previous work in both indoor (Azarmi et al., 2014; Kumar and Morawska, 2014), outdoor roadside (Al-Dabbous and Kumar, 2014a; Carpentieri and Kumar, 2011) and transport micro-environments (Goel and Kumar, 2015; Joodatnia et al., 2013a, b). Further details about the working principle and sensitivity of the DMS50 can be found in Kumar et al. (2010).

A GRIMM particle spectrometer was used to measure the mass distribution of particles per unit volume of air by light scattering technology using an optical size of $0.3-20 \mu \mathrm{m}$ in 15 different channels with a mass concentration range of $0.1-$ $100,000 \mu \mathrm{g} \mathrm{m}^{-3}$ (Goyal and Kumar, 2013). The sensitivity of the instrument is $1 \mu \mathrm{g}$ $\mathrm{m}^{-3}$, and instrument reproducibility of size-resolved particle mass concentration is $\pm 2 \%$ over the total measuring range. Optical signals pass through a multichannel size classifier to a pulse height analyser that classifies the signals based on size into appropriate channels. Ambient air was drawn into the unit every 6 second via an internal volume-controlled pump at a rate of 1.2 lit min $^{-1}$ (Goyal and Kumar, 2013; Grimm and Eatough, 2009).

A weather station (KESTREL 4500) was used to log meteorological (relative humidity, barometric pressure and ambient temperature) data at every $10 \mathrm{~s}$ at the measurement site. Outdoor ambient meteorological data, which also included wind speed and direction, was collected from a close by weather station which is run the UK Met Office. This outdoor weather station is located in the rural area of Wisley (Surrey) and the UK Met Office maintains the quality control of the collected data. These data have also been used by past studies for their scientific assessment (e.g. Burt and Eden, 2004; Al-Dabbous and Kumar, 2014a).

Cite this article as: Azarmi, F., Kumar, P., Mulheron, M., Colauxc, J.L., Jeynes, C., Adhami, S., Watts, J.F., 2015. Physicochemical characteristics and occupational exposure to coarse, fine and nanoparticle emissions during building refurbishment activities, Journal of Nanoparticle Research 17, 343, doi: 10.1007/s11051-015-3141-z. Online link: http://dx.doi.org/10.1007/s11051-015-3141-z 


\subsection{Physicochemical analysis}

Five samples, namely samples 1-5, were collected on PTFE filters that had a diameter of $47 \mathrm{~mm}$ and a nominal thickness of $\sim 1000 \mu \mathrm{g} \mathrm{cm}^{-2}$. Mass of particles was collected on filters 1, 2 and 5 during the refurbishment activities. In order to evaluate the background levels of particles, sample 3 was collected on the same site but on a separate day when the refurbishment activities were completed. Sample 4 was a "blank filter" which was not exposed to any experimental activity. This sample was analysed to set the baseline levels of various elemental species present within the filters. Details on the sampling duration and mass collected on the sampled filters are provided in Table 1.

Each of these samples were firstly analysed using a JEOL SEM (model: JSM-7100F) to provide information on the surface morphology of the particles collected on filters. The sample surface was scanned with a high-energy $(\sim 3.0 \mathrm{kV})$ beam of electrons in a raster pattern. The scanned area was between $6 \times 6$ and $200 \times 200 \mu \mathrm{m}^{2}$ according to the magnification used. The electrons interact with the atoms that make up the sample producing signals, which contain information about the sample's surface topography, composition and other properties such as electrical conductivity (Watt, 1997).

Table 1. Summary of samples collected on PTFE filters during the refurbishment activity.

\begin{tabular}{llll}
\hline Name & Date of sampling & $\begin{array}{l}\text { Net time for } \\
\text { sampling } \\
\left(\mathrm{min}^{-1}\right)\end{array}$ & $\begin{array}{l}\text { Net mass of particles } \\
\text { collected on the filter } \\
\left(\mu \mathrm{cm}^{-2}\right)\end{array}$ \\
\hline Sample 1 & 2 and 3 July 2013 & 804 & 21.8 \\
Sample 2 & 4 and 5 July 2013 & 647 & 24.4 \\
Sample 3 & 6 July 2013 & 459 & 4.6 \\
Sample 4 & Blank & 0 & 0 \\
Sample 5 & $\begin{array}{l}\text { 9, 10 and 11 July } \\
\text { 2013 }\end{array}$ & 1333 & 0.6 \\
\hline
\end{tabular}

Cite this article as: Azarmi, F., Kumar, P., Mulheron, M., Colauxc, J.L., Jeynes, C., Adhami, S., Watts, J.F., 2015. Physicochemical characteristics and occupational exposure to coarse, fine and nanoparticle emissions during building refurbishment activities, Journal of Nanoparticle Research 17, 343, doi: 10.1007/s11051-015-3141-z. Online link: http://dx.doi.org/10.1007/s11051-015-3141-z 
X-ray Photoelectron Spectroscopy (XPS) analyses were also performed on a Thermo Scientific Theta Probe spectrometer (East Grinstead, UK) to analyse the surface chemistry of the particles collected on the filter samples. XPS spectra were acquired by applying a Thermo digital twin anode source, which was operated using the $\mathrm{Al} \mathrm{K} \alpha$ at $300 \mathrm{~W}$; quantitative surface chemical analyses were calculated from the high resolution, core level spectra following the removal of a non-linear background (SI Section S2). The manufacturer's software (Avantage version 4.74) was used to analyse the results. The software incorporates the appropriate sensitivity factors and corrects for the electron energy analyser transmission function and effective attenuation length. Further details of working principle of the XPS can be seen elsewhere (Watts and Wolstenholme, 2003).

The non-destructive Ion Beam Analysis (IBA) was also applied on all the samples for investigating the chemical composition of particulate matter sampled on the filters. Elemental analysis was carried out using $2.5 \mathrm{MeV}$ proton beam, focused to about $6 \times 6 \mu \mathrm{m}^{2}$ and scanned over an area of $1000 \times 1000$ or $2000 \times 2000 \mu \mathrm{m}^{2}$ on the sample, with both particle backscattering (EBS) and particle-induced X-ray emission (PIXE) data collected and treated self-consistently (Jeynes et al., 2012) using the DataFurnace code, NDFv9.5e (Barradas and Jeynes, 2008). The EBS spectrum was essentially used for deriving the number of incident particles from the yield of the filter (i.e. $\mathrm{C}_{2} \mathrm{~F}_{4}$ ). In principle, the particle spectrum also contains valuable information about the light elements (atomic number $<12$ ) for which the PIXE is essentially blind (due to the Be filter placed in front of the SiLi detector for stopping the intense flux of backscattering particles). In our case, this quantification was unfortunately not available due to the large signal of alpha particles emitted by the ${ }^{19} \mathrm{~F}\left(\mathrm{p}, \mathrm{\alpha}_{0-4}\right)^{16} \mathrm{O}$ nuclear reactions. Besides, the strong gamma yield induced by the ${ }^{19} \mathrm{~F}\left(\mathrm{p}, \mathrm{p}^{\prime} \gamma\right){ }^{19} \mathrm{~F}$ nuclear reaction $(\mathrm{E} \gamma=110$ and $197 \mathrm{keV})$ drastically increased the background of the PIXE spectrum, making the minimum detection limits significantly higher than usual. Despite these limitations, interesting information

Cite this article as: Azarmi, F., Kumar, P., Mulheron, M., Colauxc, J.L., Jeynes, C., Adhami, S., Watts, J.F., 2015. Physicochemical characteristics and occupational exposure to coarse, fine and nanoparticle emissions during building refurbishment activities, Journal of Nanoparticle Research 17, 343, doi: 10.1007/s11051-015-3141-z. Online link: http://dx.doi.org/10.1007/s11051-015-3141-z 
about the elements with an atomic number $>12$ became available from the PIXE analysis.

\subsection{Estimation of exposure doses}

The analysis of the potential health risk of occupants associated with inhalation exposure of PM and UFPs was carried out based on estimated respiratory deposition dose rates. Construction workers are frequently exposed to inhale particles, particularly UFPs, at building refurbishment sites. The total dose received by an individual is related to the breathing rate, the period of exposure and the difference between the number of particles inhaled and exhaled during each breath (Hofmann, 2011). Including algebraic and semi-empirical deposition models, the inhalation and deposition of particles through the respiratory tract can be estimated in a number of ways. The deposition fraction model of the International Commission on Radiological Protection (ICRP, 1994) is a commonly accepted approach and is applied here and in our previous work (Azarmi et al., 2014; Goel and Kumar, 2015). Tidal volume and breathing rate depend on age, gender and the level of activity (Int Panis et al., 2010; Joodatnia et al., 2013a). Multiplication of the tidal volume and the breathing frequency determines the so-called one minute ventilation (VE). There are two approaches for calculating the dose rate. The first method utilised sizedependant DFs that were taken by the ICRP respiratory deposition model (Hofmann, 2011; ICRP, 1994) and the other uses average size resolved PNCs for each activity. The second method utilised a single DF and the average PNC for each activity. The latter approach is usually applied in situations where information on size-resolved concentration distributions is not available. Our measurements provided the detailed size distributions of particles and therefore we used both the fixed-and variable-DF approaches to estimate the dose rate in this study using Eqs. (1) and (2), respectively;

$$
\begin{aligned}
& \text { Deposited Dose }(\text { with constant } D F)=(V T \times f) \times D F \sum_{i=1}^{32} P N C(i) \\
& \text { Deposited Dose }(\text { with variable } D F)=(V T \times f) \sum_{i=1}^{32} P N C(i) \times D F(i)
\end{aligned}
$$

Where $\mathrm{PNC}_{i}$ and $\mathrm{DF}_{i}$ are the number concentration and deposited fraction of particles in each size range (i), respectively. $V T$ is tidal volume that is considered Cite this article as: Azarmi, F., Kumar, P., Mulheron, M., Colauxc, J.L., Jeynes, C., Adhami, S., Watts, J.F., 2015. Physicochemical characteristics and occupational exposure to coarse, fine and nanoparticle emissions during building refurbishment activities, Journal of Nanoparticle Research 17, 343, doi: 10.1007/s11051-015-3141-z. Online link: http://dx.doi.org/10.1007/s11051-015-3141-z 
equal to $800 \mathrm{~cm}^{-3}$ per breath for male; $f$ is the typical breathing frequency for male in working light exercise, which is taken as 0.35 breath per second (Hinds, 1999) and a constant DF value is taken as 0.65 (Chalupa et al., 2004; Int Panis et al., 2010; Joodatnia et al., 2013a).

Eq. (3) is used for the estimation of mass-based exposure, based on fixed-DF values, for various PM fractions.

$$
\text { Deposited Dose }(\text { with constant } D F)=(V T \times f \times D F) \sum P M C
$$

Where $V T$ and $f$ are considered as described above. Where PMC is particles mass concentration and DF is considered $0.86,0.60$ and 0.23 for $\mathrm{PM}_{10}, \mathrm{PM}_{2.5}$ and $\mathrm{PM}_{1}$, respectively, as average values in accordance with geometrical size mean value (Hinds, 1999). Therefore with multiplying constant value (which is the product of $V T, f$ and $\mathrm{DF}) \sim 0.014,0.010$ and $0.038 \mathrm{~m}^{3} \mathrm{~min}^{-1}$ to $\mathrm{PM}_{10}, \mathrm{PM}_{2.5}$ and $\mathrm{PM}_{1}$ values, respectively, will provide mass-based respiratory deposited doses.

\section{RESULTS AND DISCUSSION}

In order to understand the characteristics of particles during different refurbishment and non-refurbishment periods, the measured data of particles in the $5-10,000 \mathrm{~nm}$ size range is divided into three time periods. These included: (i) the "background period" at the site that was measured at one of the weekend days when no refurbishment work was taking place at the site to establish local background concentrations, (ii) the "activity period" when different refurbishment activities were taking place at the site during the working hours, and (iii) the "non-activity period" which represent times during the activity period on working days when workers did not perform any activity for at least an hour or more due to lunch breaks or some other reasons. The non-activity period was important to understand the levels of particle concentrations with respect to background and activity periods.

Cite this article as: Azarmi, F., Kumar, P., Mulheron, M., Colauxc, J.L., Jeynes, C., Adhami, S., Watts, J.F., 2015. Physicochemical characteristics and occupational exposure to coarse, fine and nanoparticle emissions during building refurbishment activities, Journal of Nanoparticle Research 17, 343, doi: 10.1007/s11051-015-3141-z. Online link: http://dx.doi.org/10.1007/s11051-015-3141-z 


\subsection{Number and size distribution of particles}

Figure 2 presents an overall picture of the average PNDs measured during the background, activity and non-activity periods. The PND spectrum during the activity period was found to be multi-modal and higher than those obtained during the non-activity period (Figure 2). Background periods showed notably lower magnitude of PNDs compared with the activity and non-activity periods that exhibited two clear peaks at about 27 and $80 \mathrm{~nm}$. These two peaks were nonexistent during background measurements, clearly showing a significant release of particles from the refurbishment activities in the UFP size range. These observations are in line with the earlier laboratory studies (Azarmi et al., 2014), showing release of UFPs during the construction activities.

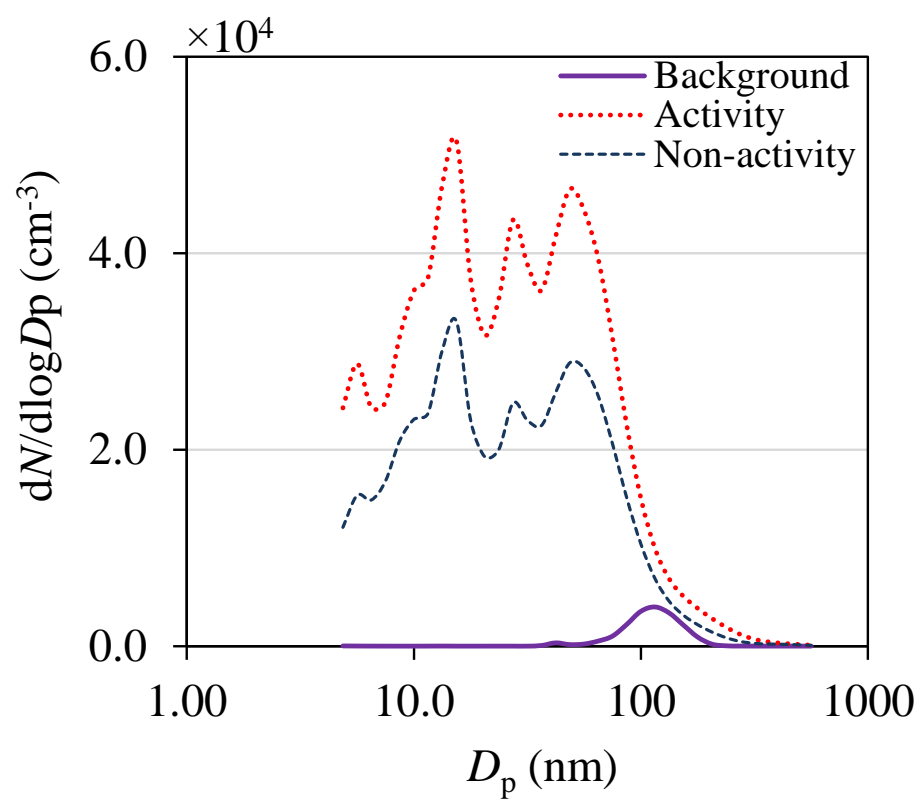

Figure 2. Average PNDs during the background, activity and non-activity periods.

Cite this article as: Azarmi, F., Kumar, P., Mulheron, M., Colauxc, J.L., Jeynes, C., Adhami, S., Watts, J.F., 2015. Physicochemical characteristics and occupational exposure to coarse, fine and nanoparticle emissions during building refurbishment activities, Journal of Nanoparticle Research 17, 343, doi: 10.1007/s11051-015-3141-z. Online link: http://dx.doi.org/10.1007/s11051-015-3141-z 


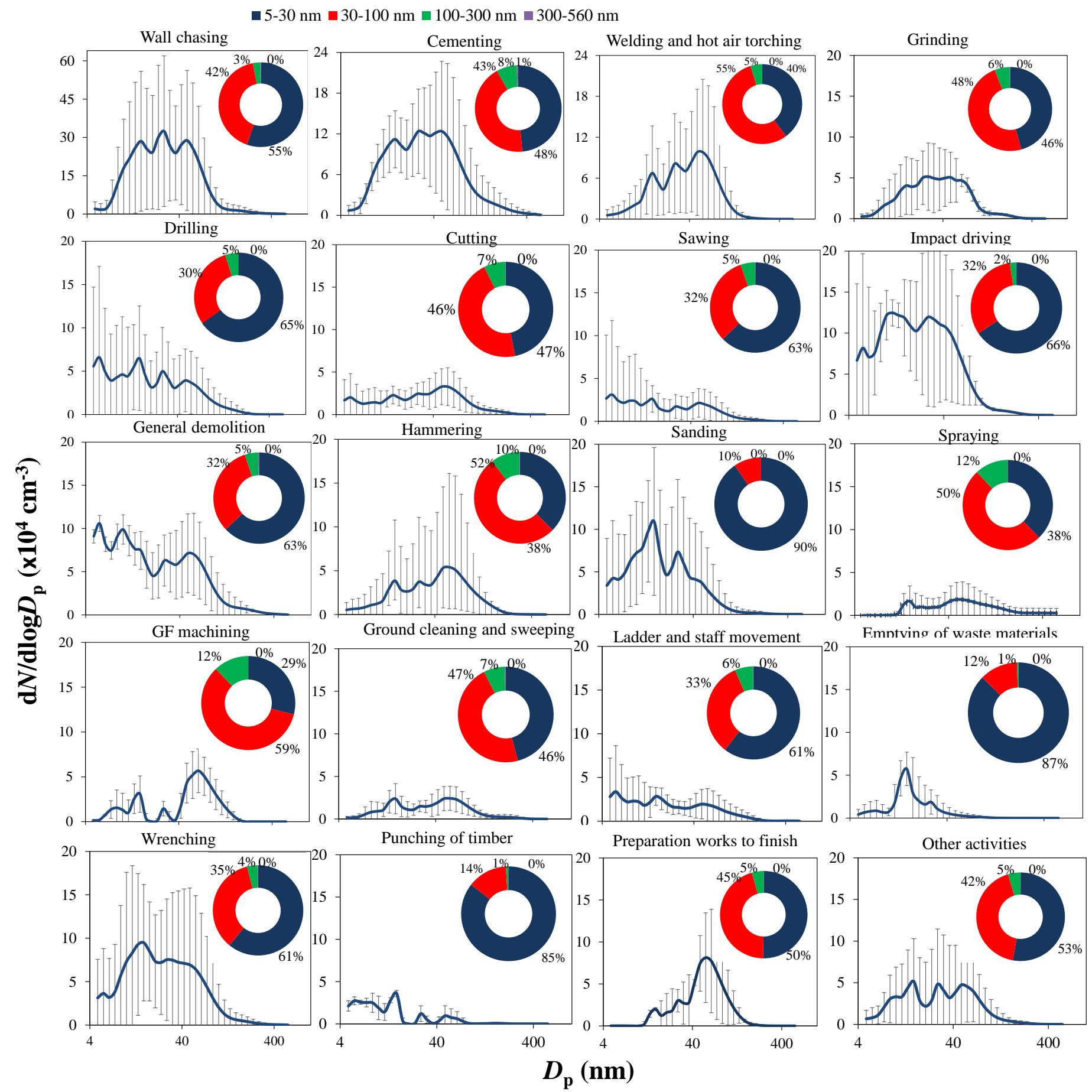

Figure 3. Average PNDs and proportion of PNCs in various size ranges for the individual activities. Other activities refer to painting, oiling, carrying metal bars to the site and moving demolished debris.

Cite this article as: Azarmi, F., Kumar, P., Mulheron, M., Colauxc, J.L., Jeynes, C., Adhami, S., Watts, J.F., 2015. Physicochemical characteristics and occupational exposure to coarse, fine and nanoparticle emissions during building refurbishment activities, Journal of Nanoparticle Research 17, 343, doi: 10.1007/s11051-015-3141-z. Online link: http://dx.doi.org/10.1007/s11051-015-3141-z 
A number of individual refurbishment activities were identified during the activity period. Their name and associated time periods are presented in SI Table S1. Figure 3 presents the average PND spectrums measured during these activities and corresponding peak diameters observed are presented in SI Table S2. These individual activities show remarkably different PND spectrums, with multiple modes and varying peak diameters. One of the interesting observations seen from SI Table S2 is that activities such as sawing and sanding that involve wood present lower peak diameters compared with those activities such as grinding and cutting involving concrete. These differences can be attributed to the differences in the mechanical process that create these particles, which are also expected to have different material composition. However, one of the common features of the PND from all the activities observed is that the majority of particles are in UFP range. This range was dominated by a significant proportion of sub-30 nm size particles that contributed up to $90 \%$ of total PNCs (Figure 3). Earlier work of Kumar et al. (2014) on concrete recycling also found multimodal PNDs, showing peak diameters at $\sim 15,27$ and $56 \mathrm{~nm}$ with significant quantities of the particles below $30 \mathrm{~nm}$ in diameter.

Wall chasing activity was observed to produce a greatest concentration in terms of release of new particles, reflecting the effect of abrasion between the wall surface and the chasing drill material. An overall increase over the background levels (Figure 2) during these activities clearly indicates the emissions of new particles. However, these results did not allow us to draw conclusions on their formation pathways, i.e. whether these emissions are arising from electric motors of different tools used such as those analysed by He et al. (2004) and Gomez et al. (2014) or through other novel mechanism, suggesting a need of dedicated studies in future. In addition, transformation processes such as coagulation, condensation, nucleation and deposition act simultaneously on the number and size distributions of particles. These processes lead to both increase (e.g. nucleation) and decrease (e.g. coagulation and deposition) in PNCs (Kumar et al., 2011a). Coagulation is an aggregation of particles and this aggregation is a function of both the residence time Cite this article as: Azarmi, F., Kumar, P., Mulheron, M., Colauxc, J.L., Jeynes, C., Adhami, S., Watts, J.F., 2015. Physicochemical characteristics and occupational exposure to coarse, fine and nanoparticle emissions during building refurbishment activities, Journal of Nanoparticle Research 17, 343, doi: 10.1007/s11051-015-3141-z. Online link: http://dx.doi.org/10.1007/s11051-015-3141-z 
of particles in an experimental setting and their ambient number concentrations (Hinds, 1999). We measured a typical average concentration in the range of $\sim 10^{4}$ $\mathrm{cm}^{-3}$ (Section 3.2) with the highest PNCs being of the order of $\sim 10^{6} \mathrm{~cm}^{-3}$ during wall chasing (SI Table S3). The time taken for the $10^{4}$ and $10^{6} \mathrm{~cm}^{-3}$ in doubling the size of particles through monodisperse coagulation is about 16 days and $4 \mathrm{~h}$, respectively (Hinds, 1999). This time is much greater than both our sampling rate $(10 \mathrm{~Hz})$ and the air exchange rates at the site (a few 10's of minutes), meaning that the effect of aggregation on measured PNCs can be overlooked.

\subsection{Particle number concentrations}

Average PNCs on a daily basis including background, activity and non-activity periods are summarised in Table 2 and their proportions in various size ranges are shown in Figure 4 . The overall average PNCs $\left(49.14 \pm 32.80 \times 10^{3}\right)$ during the activity periods were significantly above the background level $\left(1.17 \pm 0.80 \times 10^{3}\right)$ and showed noteworthy variation from day to day with maximum values being about twice the average. However, the fraction of average PNCs in the 5-30 nm, 30-100 $\mathrm{nm}$ and 100-300 nm ranges during the activity and non-activity periods remained nearly unchanged (Figure 4). There was a much larger change to PNCs in the 5-30 nm size range that, for example, increased from $~ 0.2 \%$ during background to 56 and 55\% during activity and non-activity periods, respectively. Such a change was modest (within 6\%) between background and activity/non-activity periods for the particles in the 30-100 nm range.

Cite this article as: Azarmi, F., Kumar, P., Mulheron, M., Colauxc, J.L., Jeynes, C., Adhami, S., Watts, J.F., 2015. Physicochemical characteristics and occupational exposure to coarse, fine and nanoparticle emissions during building refurbishment activities, Journal of Nanoparticle Research 17, 343, doi: 10.1007/s11051-015-3141-z. Online link: http://dx.doi.org/10.1007/s11051-015-3141-z 


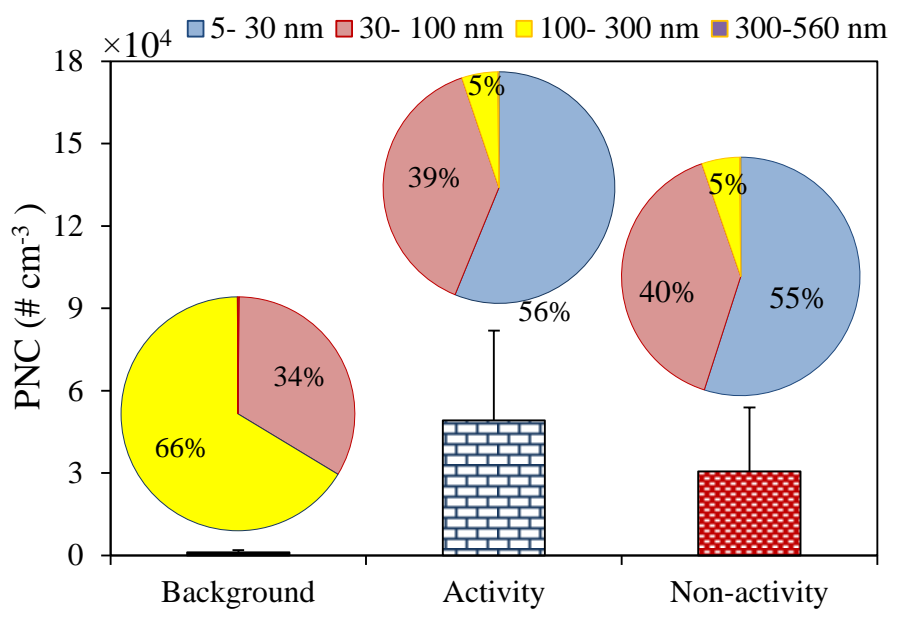

Figure 4. Average PNCs during the background, activity and non-activity periods.

Figure 5 shows the average PNCs measured over each sampling day and their fractions in various size ranges for individual activities (irrespective of their use on materials type such as concrete, bricks or metal) are presented in SI Table S3. Average PNCs during all the various activities significantly exceeded measured background levels. The results also demonstrate that drilling of concrete produces much higher PNCs in comparison with drilling of metal or other materials like polyvinyl chloride. For all these activities, the ultrafine size range (5-100 nm) accounted for the majority of the total PNCs (Figures 5 and SI Figure S1). For example, their proportion to total PNCs during the wall chasing, general demolition, cementing, welding, cutting, wrenching with using gas grips and impact driving on woody boards was between 91 and 97\% (Figure 3). A major fraction of these UFPs is below $30 \mathrm{~nm}$ (Figure 5), which are generally formed through gas-to-particle conversion (Kulmala et al., 2004; Kumar et al., 2010), but information of such precursor gases were unavailable. It may be the case that the attrition between the surfaces of equipment and building materials during high rotational frequency have produced precursor gases, however, further investigations are clearly needed to reach to a clear consensus.

Cite this article as: Azarmi, F., Kumar, P., Mulheron, M., Colauxc, J.L., Jeynes, C., Adhami, S., Watts, J.F., 2015. Physicochemical characteristics and occupational exposure to coarse, fine and nanoparticle emissions during building refurbishment activities, Journal of Nanoparticle Research 17, 343, doi: 10.1007/s11051-015-3141-z. Online link: http://dx.doi.org/10.1007/s11051-015-3141-z 
Table 2. Average values of PNCs during the background, activity and non-activity periods on different days.

\begin{tabular}{lccc}
\hline Activity days & Background & $\begin{array}{l}\text { PNC during activity periods } \\
\pm \text { Standard deviation }\left(\# \mathrm{~cm}^{-3}\right)\end{array}$ & $\begin{array}{l}\text { PNC during non-activity periods } \\
\pm \text { Standard deviation }\left(\# \mathrm{~cm}^{-3}\right)\end{array}$ \\
\hline & $1.17 \pm 0.80 \times 10^{3}$ & --- & -- \\
1 & --- & $21.37 \pm 9.34 \times 10^{3}$ & $11.33 \pm 9.63 \times 10^{3}$ \\
2 & --- & $26.99 \pm 27.18 \times 10^{3}$ & $5.60 \pm 3.70 \times 10^{3}$ \\
3 & --- & $34.09 \pm 22.07 \times 10^{3}$ & $27.90 \pm 20.06 \times 10^{3}$ \\
4 & --- & $20.357 \pm 15.11 \times 10^{3}$ & $10.89 \pm 6.66 \times 10^{3}$ \\
5 & --- & $97.84 \pm 129.50 \times 10^{3}$ & $48.76 \pm 42.31 \times 10^{3}$ \\
6 & --- & $91.04 \pm 51.07 \times 10^{3}$ & $68.24 \pm 42.74 \times 10^{3}$ \\
7 & --- & $52.31 \pm 39.68 \times 10^{3}$ & $41.27 \pm 33.65 \times 10^{3}$ \\
\hline
\end{tabular}

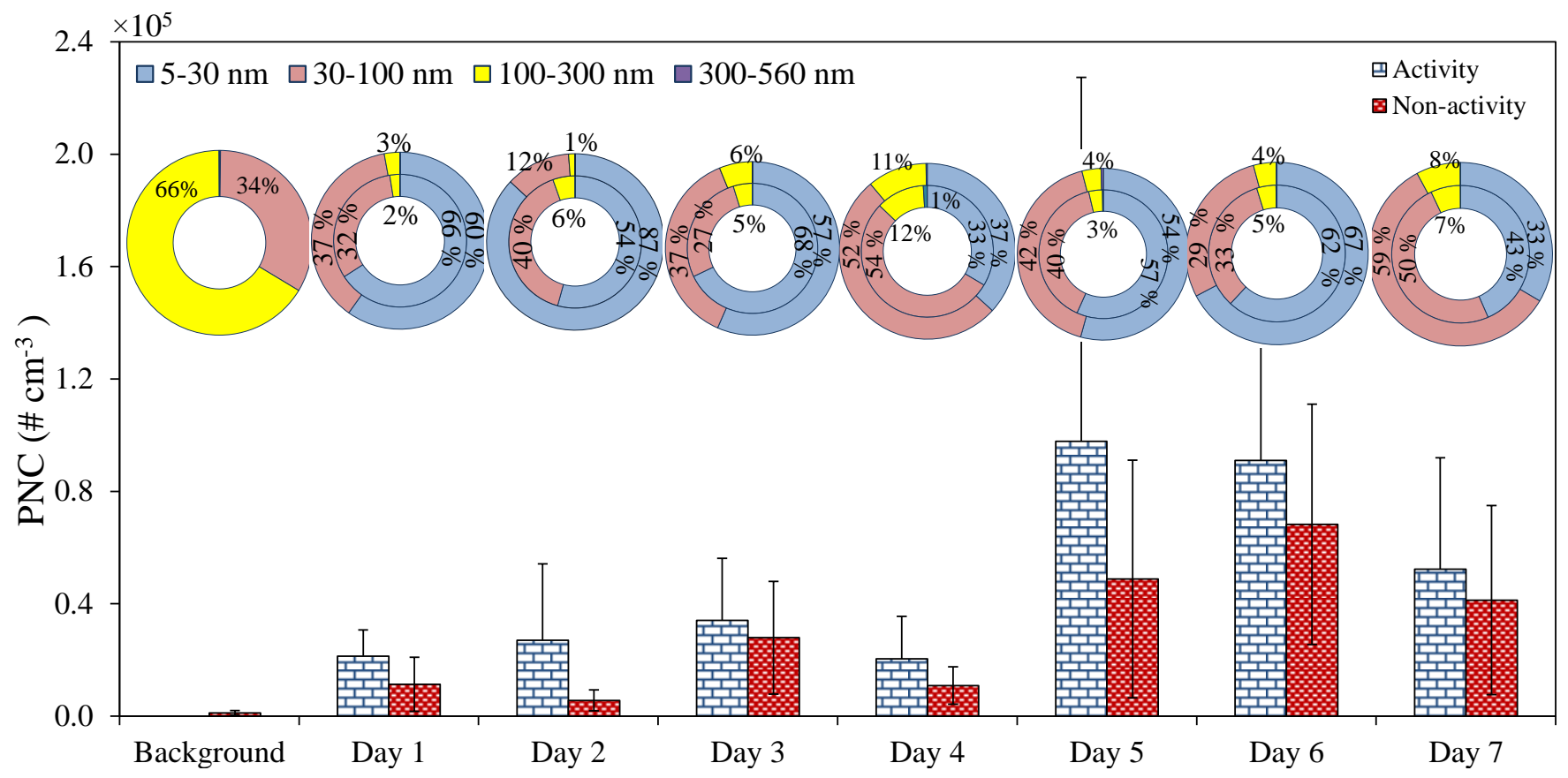

Figure 5. The Average PNCs on a daily basis during the background, activity and nonactivity periods. The inner and outer circles represent fractions of PNCs in various size ranges during the activity and non-activity periods, respectively.

Cite this article as: Azarmi, F., Kumar, P., Mulheron, M., Colauxc, J.L., Jeynes, C., Adhami, S., Watts, J.F., 2015. Physicochemical characteristics and occupational exposure to coarse, fine and nanoparticle emissions during building refurbishment activities, Journal of Nanoparticle Research 17, 343, doi: 10.1007/s11051-015-3141-z. Online link: http://dx.doi.org/10.1007/s11051-015-3141-z 
The average values of PNCs during our general demolition activity at refurbishment site were $~ 2$-times lower than those reported by Kumar et al. (2012c) during simulation of slab demolition in the laboratory. Furthermore, our results of average PNCs during the drilling activity $\left(5.22 \pm 4.44 \times 10^{4} \mathrm{~cm}^{-3}\right)$ was $\sim 5$-times lower compared with laboratory studies of Azarmi et al. (2014). This is expected because the emissions in laboratory work were measured close to the source. However, the activities in this work occurred a few meters away from the sampling point to give emission relatively larger time to dilute before measurements.

\subsection{Particle mass concentrations}

Figure 6 shows the overall average of $\mathrm{PM}_{10}, \mathrm{PM}_{2.5}$ and $\mathrm{PM}_{1}$ during the background, activity and non-activity periods. These PM fractions were found to be significantly above the background levels (Table 3). For instance, $\mathrm{PM}_{10}, \mathrm{PM}_{2.5}$ and $\mathrm{PM}_{1}$ were up to 2- and 43-times larger during the activity periods than those during subsequent periods of non-activity and background, respectively (Figure 7). Our results are not directly comparable to other studies, but similar trend in increased concentrations were observed by the other field studies. For example, Hansen et al. (2008) found a 2.9- and 3.3-times increase in concentration for particles larger than 0.5 and $0.1 \mu \mathrm{m}$ in size, respectively, during the demolition of a hospital building. The average $\mathrm{PM}_{10}$ concentrations measured during refurbishment activities found to

Cite this article as: Azarmi, F., Kumar, P., Mulheron, M., Colauxc, J.L., Jeynes, C., Adhami, S., Watts, J.F., 2015. Physicochemical characteristics and occupational exposure to coarse, fine and nanoparticle emissions during building refurbishment activities, Journal of Nanoparticle Research 17, 343, doi: 10.1007/s11051-015-3141-z. Online link: http://dx.doi.org/10.1007/s11051-015-3141-z 
exceed by about 20-times the 24-h mean European limit values of $50 \mu \mathrm{g} \mathrm{m}^{-3}$ (EU Directive, 1999).

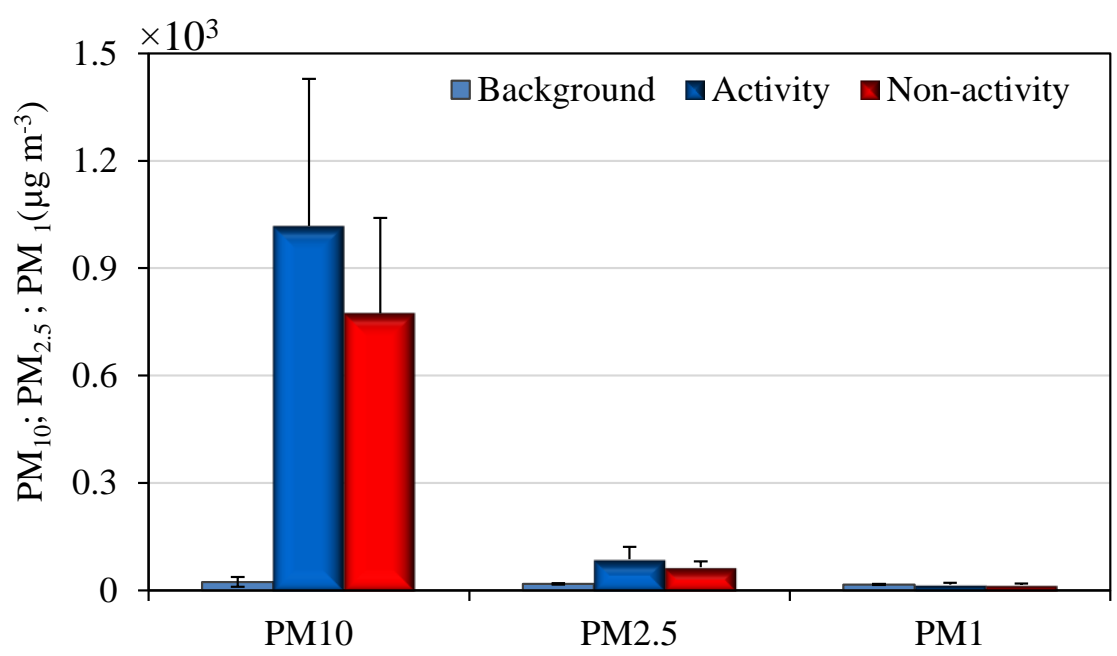

Figure 6. The concentrations of $\mathrm{PM}_{10}, \mathrm{PM}_{2.5}$ and $\mathrm{PM}_{1}$ during the background, activity and non-activity periods.

Table 3. The concentrations of $\mathrm{PM}_{10}, \mathrm{PM}_{2.5}$ and $\mathrm{PM}_{1}$ during the background, activity and nonactivity periods on different days.

\begin{tabular}{|c|c|c|c|c|c|c|}
\hline \multirow{2}{*}{$\begin{array}{l}\text { Sampling } \\
\text { days } \\
\text { Background }\end{array}$} & \multicolumn{2}{|c|}{$\begin{array}{c}\mathrm{PM}_{10} \\
\text { Average } \pm \text { Standard deviation } \\
\left(\times 10^{2} \mu \mathrm{g} \mathrm{m}^{-3}\right)\end{array}$} & \multicolumn{2}{|c|}{$\begin{array}{c}\mathrm{PM}_{2.5} \\
\text { Average } \pm \text { Standard deviation } \\
\left(\times 10^{2} \mu \mathrm{g} \mathrm{m}^{-3}\right)\end{array}$} & \multicolumn{2}{|c|}{$\begin{array}{c}\mathrm{PM}_{1} \\
\text { Average } \pm \text { Standard deviation } \\
\left(\times 10^{2} \mu \mathrm{g} \mathrm{m}^{-3}\right)\end{array}$} \\
\hline & - & $0.19 \pm 0.04$ & - & $0.16 \pm 0.01$ & - & $0.14 \pm 0.00$ \\
\hline & Activity & Non-activity & Activity & Non-activity & Activity & Non-activity \\
\hline 1 & $6.11 \pm 6.08$ & $5.32 \pm 3.21$ & $0.49 \pm 0.27$ & $0.45 \pm 0.14$ & $0.14 \pm 0.03$ & $0.14 \pm 0.01$ \\
\hline 2 & $10.32 \pm 7.37$ & $10.16 \pm 5.48$ & $0.69 \pm 0.46$ & $0.69 \pm 0.33$ & $0.11 \pm 0.05$ & $0.11 \pm 0.03$ \\
\hline 3 & $12.87 \pm 12.93$ & $8.34 \pm 7.78$ & $0.96 \pm 0.94$ & $0.66 \pm 0.53$ & $0.13 \pm 0.09$ & $0.10 \pm 0.04$ \\
\hline 4 & $15.93 \pm 12.28$ & $7.83 \pm 8.94$ & $1.43 \pm 0.83$ & $0.63 \pm 0.59$ & $0.20 \pm 0.92$ & $0.19 \pm 0.08$ \\
\hline 5 & $7.51 \pm 5.32$ & $7.04 \pm 3.99$ & $0.69 \pm 0.41$ & $0.65 \pm 0.37$ & $0.12 \pm 0.05$ & $0.11 \pm 0.05$ \\
\hline 6 & $5.05 \pm 3.53$ & $3.81 \pm 1.93$ & $0.62 \pm 0.35$ & $0.50 \pm 0.20$ & $0.17 \pm 0.82$ & $0.15 \pm 0.05$ \\
\hline 7 & $13.45 \pm 7.64$ & $11.60 \pm 3.65$ & $1.18 \pm 0.75$ & $0.95 \pm 0.26$ & $0.24 \pm 0.86$ & $0.19 \pm 0.03$ \\
\hline $\begin{array}{l}\text { Overall } \\
\text { average }\end{array}$ & $10.18 \pm 4.10$ & $7.73 \pm 2.67$ & $0.87 \pm 0.33$ & $0.64 \pm 0.16$ & $0.16 \pm 0.04$ & $0.14 \pm 0.03$ \\
\hline
\end{tabular}

Cite this article as: Azarmi, F., Kumar, P., Mulheron, M., Colauxc, J.L., Jeynes, C., Adhami, S., Watts, J.F., 2015. Physicochemical characteristics and occupational exposure to coarse, fine and nanoparticle emissions during building refurbishment activities, Journal of Nanoparticle Research 17, 343, doi: 10.1007/s11051-015-3141-z. Online link: http://dx.doi.org/10.1007/s11051-015-3141-z 


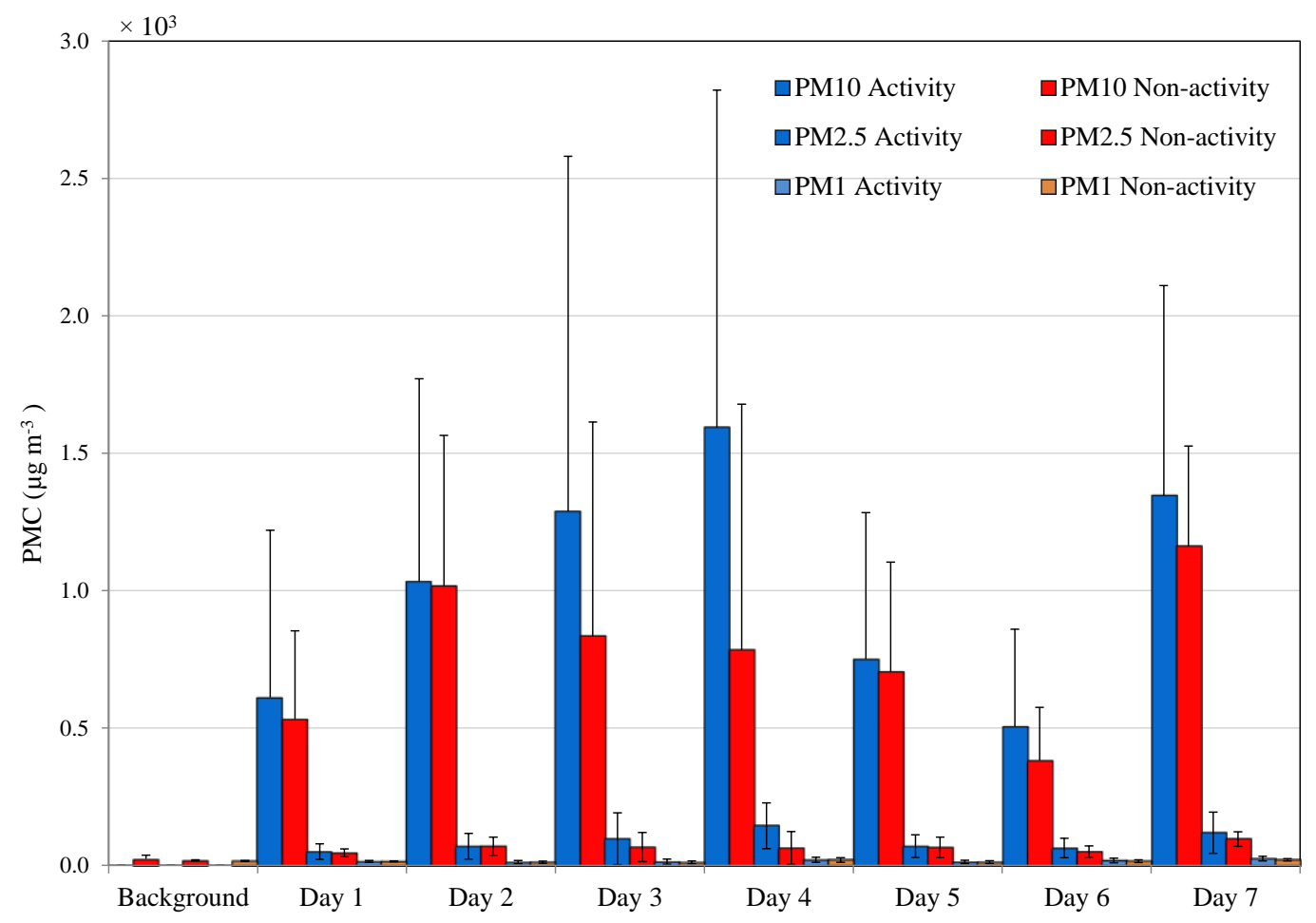

Figure 7. The average concentrations of $\mathrm{PM}_{10}, \mathrm{PM}_{2.5}$ and $\mathrm{PM}_{1}$ during the background, activity and non-activity period for each day of activity.

Cite this article as: Azarmi, F., Kumar, P., Mulheron, M., Colauxc, J.L., Jeynes, C., Adhami, S., Watts, J.F., 2015. Physicochemical characteristics and occupational exposure to coarse, fine and nanoparticle emissions during building refurbishment activities, Journal of Nanoparticle Research 17, 343, doi: 10.1007/s11051-015-3141-z. Online link: http://dx.doi.org/10.1007/s11051-015-3141-z 


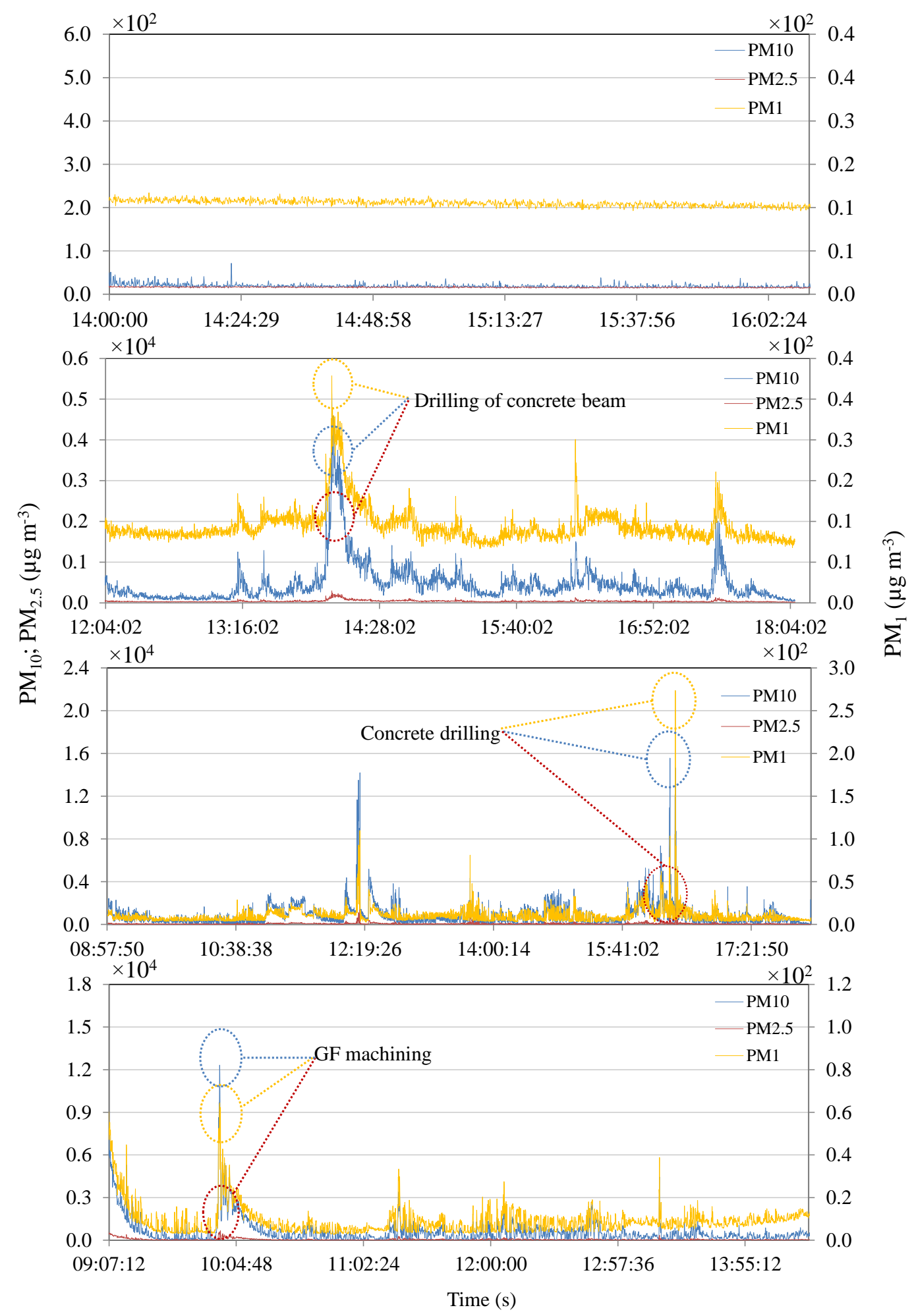

Cite this article as: Azarmi, F., Kumar, P., Mulheron, M., Colauxc, J.L., Jeynes, C., Adhami, S., Watts, J.F., 2015. Physicochemical characteristics and occupational exposure to coarse, fine and nanoparticle emissions during building refurbishment activities, Journal of Nanoparticle Research 17, 343, doi: 10.1007/s11051-015-3141-z. Online link: http://dx.doi.org/10.1007/s11051-015-3141-z 


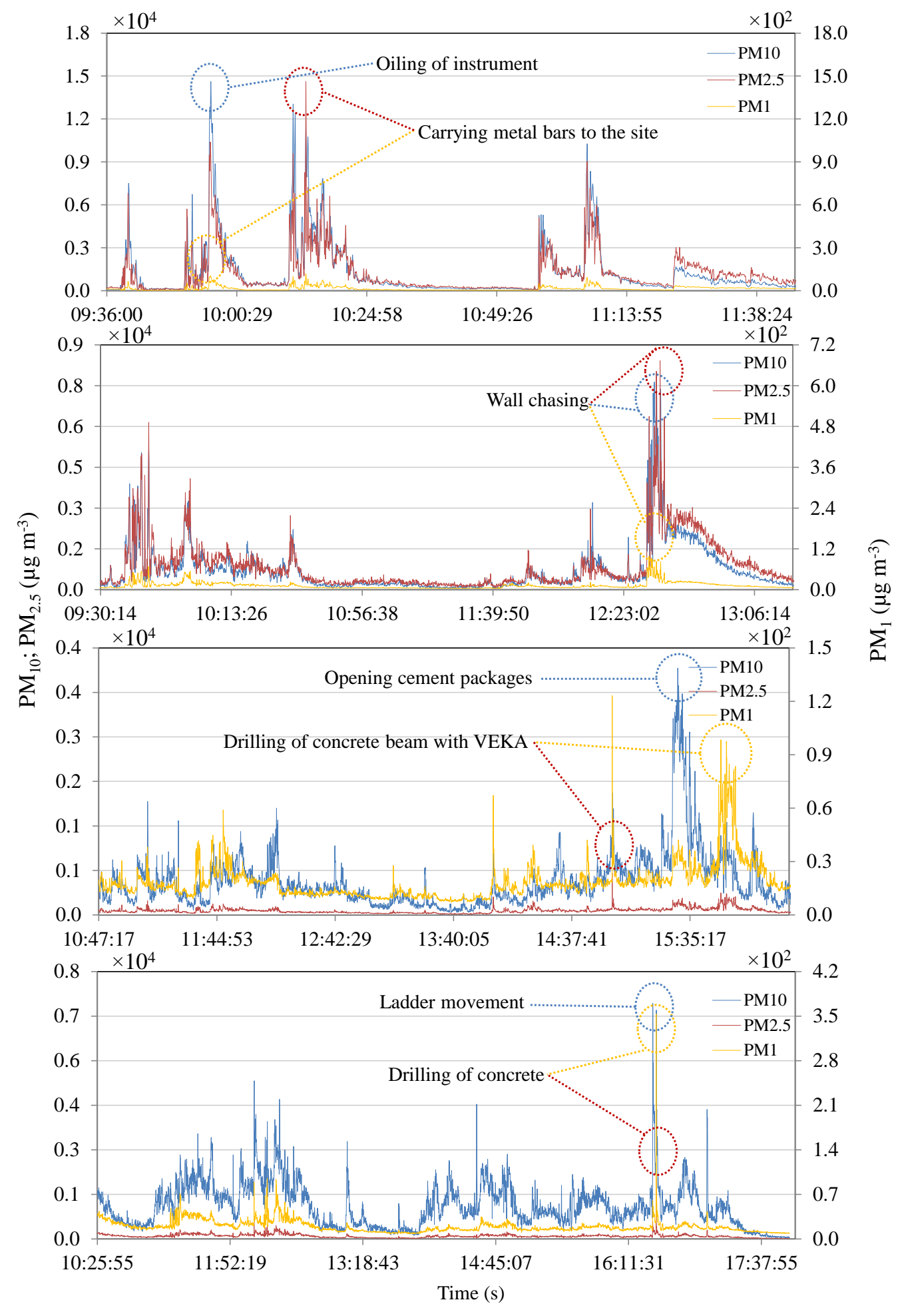

Figure 8. The concentrations of $\mathrm{PM}_{10}, \mathrm{PM}_{2.5}$ and $\mathrm{PM}_{1}$ during the background and activity period (details of each activity time period is listed in SI Table S1).

Cite this article as: Azarmi, F., Kumar, P., Mulheron, M., Colauxc, J.L., Jeynes, C., Adhami, S., Watts, J.F., 2015. Physicochemical characteristics and occupational exposure to coarse, fine and nanoparticle emissions during building refurbishment activities, Journal of Nanoparticle Research 17, 343, doi: 10.1007/s11051-015-3141-z. Online link: http://dx.doi.org/10.1007/s11051-015-3141-z 
Figure 8 confirms that PMC values exhibit a sharp increase immediately after the start of any activity and reach a peak value within a few seconds. The highest peak values for $\mathrm{PM}_{10}, \mathrm{PM}_{2.5}$ and $\mathrm{PM}_{1}$ obtained for the drilling activity were 155.60, 19.10, $3.54\left(\times 10^{2}\right) \mu \mathrm{g} \mathrm{m}^{-3}$, respectively, which is about 819, 119 and 25-times higher than the background levels. Interestingly, the wall chasing activity produced a higher PNC, but lower PMCs, than those measured during drilling operation, suggesting that the particle sizes produced by the wall chasing were (on average) smaller than those produced by drilling (SI Table S3). Possible reasons for this could be a much greater mechanical attrition between the surfaces of wall and drilling bit materials, generating coarse size particles in higher quantities during drilling.

The previous field studies have also found increase in PMCs levels during the activity periods over the background levels. For example, Dorevitch et al. (2006) measured $\mathrm{PM}_{10}$ during the demolition of a reinforced concrete building and found $6 \mathrm{~h}$ averaged concentrations up to about 10-times higher compared with predemolition levels which are background concentrations in this case. Likewise, Beck et al. (2003) found ambient levels of $\mathrm{PM}_{10}$ to increase by between 8 and 3000-times during implosion of a building compared with pre-demolition levels, depending on the distance of measurement point from the source.

\subsection{Morphology assessment and chemical characterisation}

SEM, IBA and XPS experiments were conducted on the samples collected on the filters for understanding the morphology and chemical composition of particles such as their shape, structure and chemical composition.

\subsubsection{XPS and SEM analysis}

Table 4 shows the elemental composition of all the five samples described in Table 1. The blank filter sample and background contained the main characteristics of Teflon type materials. The shape of the spectrum (SI Figure S2) indicated a thin layer of about $5 \mathrm{~mm}$ on the background and blank filters. A very strong peak for fluorine (F) was observed, followed by carbon (C) and oxygen (O) in the background (sample 3) and blank (sample 4) filters. The samples 1, 2 and 5, which were taken Cite this article as: Azarmi, F., Kumar, P., Mulheron, M., Colauxc, J.L., Jeynes, C., Adhami, S., Watts, J.F., 2015. Physicochemical characteristics and occupational exposure to coarse, fine and nanoparticle emissions during building refurbishment activities, Journal of Nanoparticle Research 17, 343, doi: 10.1007/s1 1051-015-3141-z. Online link: http://dx.doi.org/10.1007/s11051-015-3141-z 
during activity periods, also contained calcium (Ca), silicon (Si), copper $(\mathrm{Cu})$, aluminium (Al) and sulphur (S). The chemical state of Si can be associated to either organosilane or silicon dioxide $\left(\mathrm{SiO}_{2}\right)$, depending on the binding energy of the peak (SI Figure S2). This is because Si is capable of reacting with an organic compound and it is found to be present in an oxide form. Some of the $\mathrm{Al}$ and $\mathrm{S}$ compounds and organic hydrocarbons were also found on the surfaces of the filters collected during activity periods (i.e. samples 1, 2 and 5), which were thought of arising from activities such as drilling of aluminium or steel stuff, spraying (galvanizing), cementing and cutting of concrete.

Table 4. The elemental composition of the all the filters (quantitative XPS analyses).

\begin{tabular}{|c|c|c|c|c|c|c|c|c|c|}
\hline \multicolumn{2}{|c|}{ Sample 1} & \multicolumn{2}{|c|}{ Sample 2} & \multicolumn{2}{|c|}{$\begin{array}{l}\text { Sample } 3 \\
\text { (background) }\end{array}$} & \multicolumn{2}{|c|}{$\begin{array}{l}\text { Sample } 4 \\
\text { (blank) }\end{array}$} & \multicolumn{2}{|c|}{ Sample 5} \\
\hline Name & $\begin{array}{l}\text { Fraction } \\
(\%)\end{array}$ & Name & $\begin{array}{l}\text { Fraction } \\
(\%)\end{array}$ & Name & $\begin{array}{l}\text { Fraction } \\
(\%)\end{array}$ & Name & $\begin{array}{l}\text { Fraction } \\
(\%)\end{array}$ & Name & $\begin{array}{l}\text { Fraction } \\
(\%)\end{array}$ \\
\hline $\mathrm{C}$ & 37.4 & $\mathrm{C}$ & 34.9 & $\mathrm{C}$ & 31.2 & $\mathrm{C}$ & 30.3 & $\mathrm{C}$ & 34.3 \\
\hline 0 & 11.1 & 0 & 8.2 & 0 & 1.2 & 0 & 1.0 & 0 & 21.5 \\
\hline$F$ & 50.5 & $F$ & 55.3 & $F$ & 67.6 & $\mathrm{~F}$ & 68.7 & $F$ & 37.5 \\
\hline \multirow[t]{5}{*}{$\mathrm{Ca}$} & 0.9 & $\mathrm{Ca}$ & 0.6 & & & & & $\mathrm{Ca}$ & 1.5 \\
\hline & & $\mathrm{Si}$ & 0.5 & & & & & $\mathrm{Si}$ & 2.2 \\
\hline & & $\mathrm{Cu}$ & 0.2 & & & & & $\mathrm{Cu}$ & 0.3 \\
\hline & & $\mathrm{S}$ & 0.4 & & & & & $\mathrm{~S}$ & 1.2 \\
\hline & & & & & & & & $\mathrm{Al}$ & 2.0 \\
\hline
\end{tabular}

Further analysis showed that the sample 5 contained relatively heavier particles of elements such as $\mathrm{Cu}$. In addition, the intensity of the peaks of other elements such as $\mathrm{C}$, Si and $\mathrm{Al}$ was found to be increasing, mainly due to the longer exposure time and thereby leading to larger amount of absorbed particles on the filter. Considering (i) the increment in the intensity of $\mathrm{O}$ peak, (ii) its ratio with other peaks such as $\mathrm{Si}, \mathrm{Al}$ and $\mathrm{Ca}$, and (iii) comparison of the shape of the C1s peak and all the fitted peaks

Cite this article as: Azarmi, F., Kumar, P., Mulheron, M., Colauxc, J.L., Jeynes, C., Adhami, S., Watts, J.F., 2015. Physicochemical characteristics and occupational exposure to coarse, fine and nanoparticle emissions during building refurbishment activities, Journal of Nanoparticle Research 17, 343, doi: 10.1007/s11051-015-3141-z. Online link: http://dx.doi.org/10.1007/s11051-015-3141-z 
contributing toward it, suggested that these elements appear to be associated with grinding, drilling and welding activities where aluminium oxide, calcium oxide, calcium carbonate, copper oxide compounds are expected to be produced.

SEM images of the particles collected on filters were taken for understanding the morphology of particles (Figure 9). A heterogeneous structure of the sampled particles was found where the irregular shaped aggregated and spongy particles can be seen. A few irregular shaped black holes can also be seen, which represent the porosity of the filters. Differences between particles deposited on the background (sample 3) and blank (sample 4) filters and those collected during the activity periods (samples 1, 2 and 5) represents the presence of new elements (Ca, $\mathrm{Si}, \mathrm{Cu}, \mathrm{S}$ and $\mathrm{Al}$ ) arising from the refurbishment activities, and some of these elements could be in oxide form as evident by the presence of 0 (Table 4).

Cite this article as: Azarmi, F., Kumar, P., Mulheron, M., Colauxc, J.L., Jeynes, C., Adhami, S., Watts, J.F., 2015. Physicochemical characteristics and occupational exposure to coarse, fine and nanoparticle emissions during building refurbishment activities, Journal of Nanoparticle Research 17, 343, doi: 10.1007/s11051-015-3141-z. Online link: http://dx.doi.org/10.1007/s11051-015-3141-z 

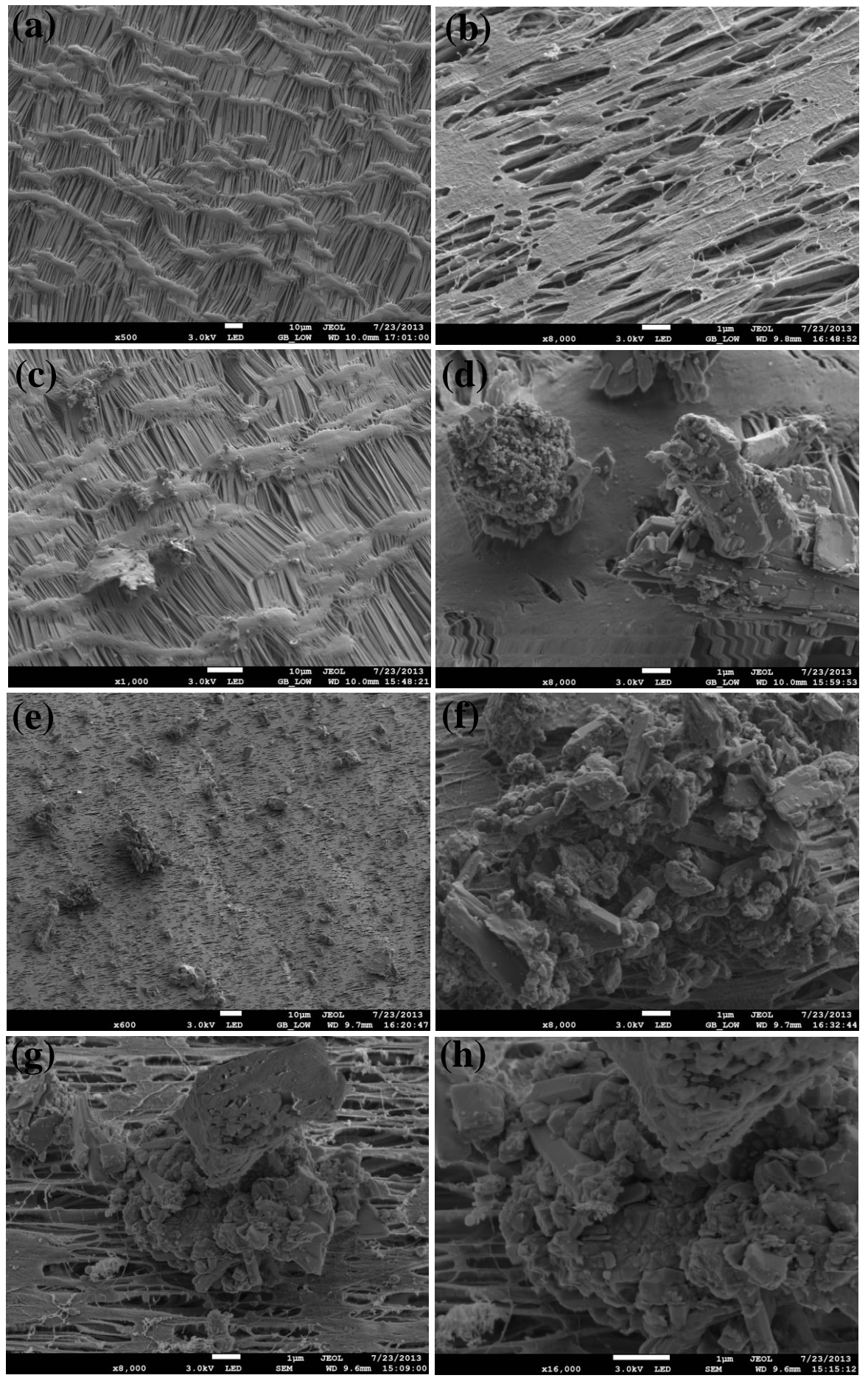

Figure 9. SEM images of (a) blank filter at $\times 500$, (b) background measurements at $\times 8000$, (c) sample 1 at $\times 1000$, (d) sample 1 at $\times 8000$, (e) sample 2 at $\times 600$, (f) sample 2 at $\times 8000$, (g) sample 5 at $\times 8000$, and (h) sample 5 at $\times 16000$.

Cite this article as: Azarmi, F., Kumar, P., Mulheron, M., Colauxc, J.L., Jeynes, C., Adhami, S., Watts, J.F., 2015. Physicochemical characteristics and occupational exposure to coarse, fine and nanoparticle emissions during building refurbishment activities, Journal of Nanoparticle Research 17, 343, doi: 10.1007/s11051-015-3141-z. Online link: http://dx.doi.org/10.1007/s11051-015-3141-z 


\subsubsection{IBA analysis}

Weight of elemental contents in parts per million ( $\mathrm{ppm})$ together with analysis uncertainties and the minimum level of detection (MLD) are shown in SI Table S4. The filters analysed in this work were much thicker $\left(\sim 3500 \mu \mathrm{g} \mathrm{cm}^{-2}\right)$ than expected $\left(\sim 1000 \mu \mathrm{g} \mathrm{cm}^{-2}\right)$ leading to degradation of the accuracy generally achievable for this kind of analysis (Cohen et al., 1996).

The Fe-containing nanoparticles tend to form large aggregates of tens of microns size. The possible reason for the high presence of $\mathrm{Ca}, \mathrm{Si}$ and $\mathrm{K}$ is thought to be due to activities related with concrete material (e.g. drilling, cutting and general demolition), which is typically made of cement, water, admixtures and aggregates (Kumar and Morawska, 2014). Furthermore, cement is made of constituents such as silicon oxide $\left(\mathrm{SiO}_{2}\right)$, calcium oxide $(\mathrm{CaO})$, aluminium oxide $\left(\mathrm{Al}_{2} \mathrm{O}_{3}\right)$, ferric oxide $\left(\mathrm{Fe}_{2} \mathrm{O}_{3}\right)$ and sulphate $(\overline{\mathrm{S}})$ that acts to bind the components of concrete together. This forms a nonporous, highly cohesive, complex structure containing 10-50 nm diameter capillary pores in well hydrated form (Raki et al., 2010). This suggests that the breaking of concrete containing small pores may produce particles in various size ranges, as seen in Figure 3 (Kumar and Morawska, 2014). The comparison between the results of this section with those presented in Section 3.4.1 shows that Fe and Zn were detected by the IBA but not by the XPS analyses. This difference is possibly due to the different detection levels of sample depth between the IBA and XPS analyses.

\subsection{Exposure assessment}

The size range of the measured particles and their concentration are key factors for the assessment of occupational exposure to ultrafine and particulate matter. We estimated the average respiratory disposition doses of PNCs using the approach described in Section 2.4 for both constant and size-dependant DFs (SI Section S3). The constant and size-dependent DFs provided the total deposited doses as $5.70 \pm 5.42$ $\times 10^{8} \mathrm{~min}^{-1}, 2.86 \pm 2.17 \times 10^{8} \mathrm{~min}^{-1}$ as well as $7.03 \pm 6.65 \times 10^{8} \mathrm{~min}^{-1}$ and $3.57 \pm 2.72$ $\times 10^{8} \mathrm{~min}^{-1}$ for refurbishment activities during the activity and non-activity periods,

Cite this article as: Azarmi, F., Kumar, P., Mulheron, M., Colauxc, J.L., Jeynes, C., Adhami, S., Watts, J.F., 2015. Physicochemical characteristics and occupational exposure to coarse, fine and nanoparticle emissions during building refurbishment activities, Journal of Nanoparticle Research 17, 343, doi: 10.1007/s11051-015-3141-z. Online link: http://dx.doi.org/10.1007/s11051-015-3141-z 
respectively (SI Table S5). These figures show much higher doses for the sizedependent DFs compared to those obtained using the constant DFs (Figure 10), mainly due to dominance of particles below $100 \mathrm{~nm}$ which is a fraction that also have the largest deposition (ICRP, 1995; Kumar et al., 2010). This highlights the importance of the availability of size distributions for an accurate exposure assessment.

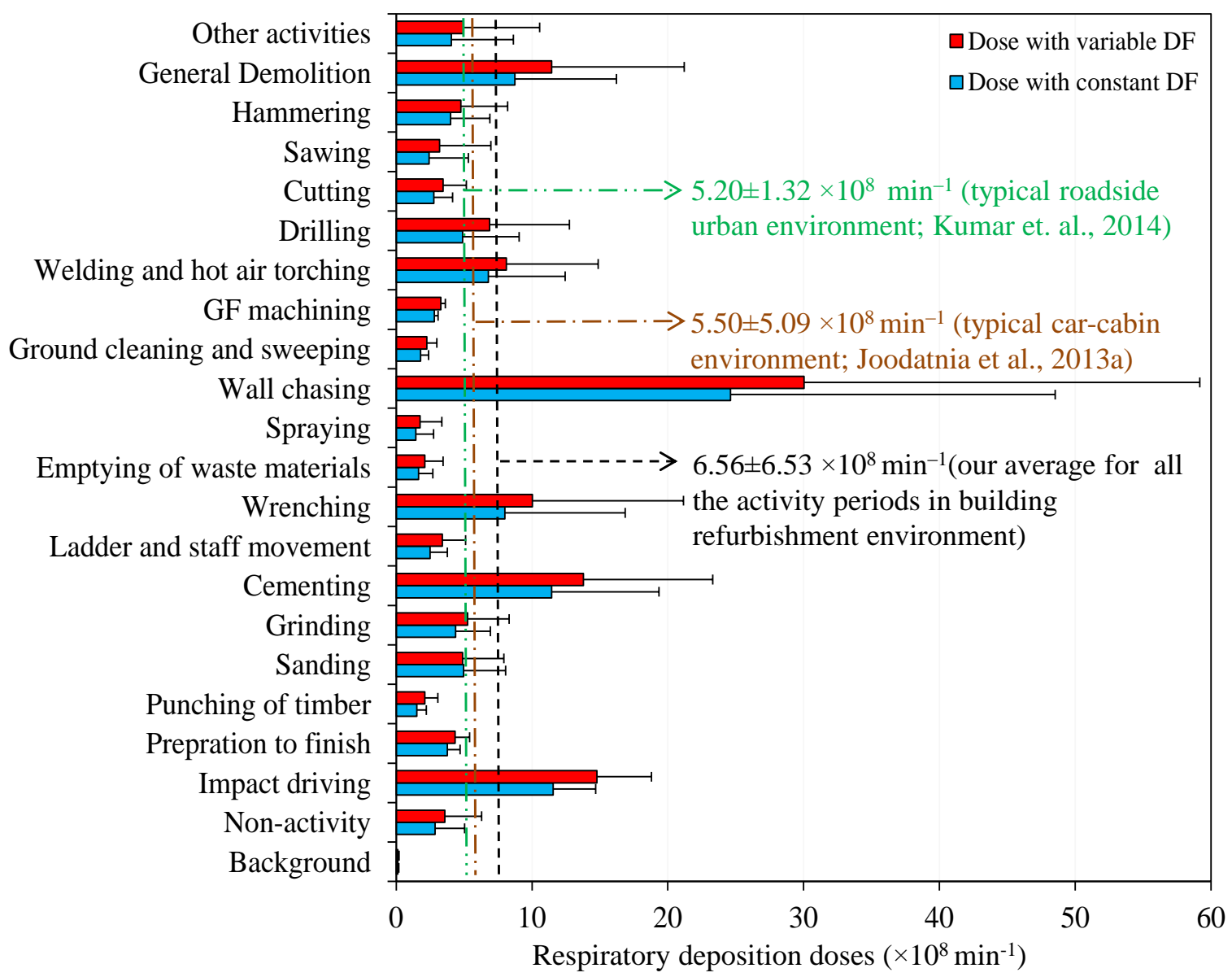

Figure 10. Respiratory tract deposition dose rate (\# $\left.\mathrm{min}^{-1}\right)$ calculated using (i) a constant DF and the average PNC during each activity and (ii) size-dependent DFs and average sizeresolved PNCs. It is worth noting that these dose rates are estimated based on the concentrations measured when these activities were in progress at the refurbishment site and should not be interpreted as direct exposure as the distance between the sampling point and activities varied. Also are shown respiratory deposition doses rate (\# min ${ }^{-1}$ ) using sizedependent DFs in roadside environment of different European cities (Kumar et al., 2014) and those experienced in typical transport microenvironment (i.e. car cabin; Joodatnia et al., 2013a).

Cite this article as: Azarmi, F., Kumar, P., Mulheron, M., Colauxc, J.L., Jeynes, C., Adhami, S., Watts, J.F., 2015. Physicochemical characteristics and occupational exposure to coarse, fine and nanoparticle emissions during building refurbishment activities, Journal of Nanoparticle Research 17, 343, doi: 10.1007/s11051-015-3141-z. Online link: http://dx.doi.org/10.1007/s11051-015-3141-z 
Lack of exposure assessment studies during refurbishment works make it challenging to directly compare our results with published literature. We have tried to pick the closest possible exposure studies for putting our results in a broad perspective. For instance, Kumar et al. (2014) summarised results of 45 sampling locations in 30 different European cities to estimate the respiratory deposition doses of PNCs in urban roadside environments. The corresponding values of such doses were found to be $5.20 \pm 1.32 \times 10^{8} \mathrm{~min}^{-1}$ in roadside European environments. Likewise, Joodatnia et al. (2013a) estimated the average respiratory doses as $5.50 \pm 5.09 \times 10^{8} \mathrm{~min}^{-1}$ over 30 car journeys in Guildford, UK. Our respiratory deposited doses for refurbishment activities are nearly one and a half times higher than those shown by both studies. These observations clearly indicate that the occupational exposure to workers on refurbishment site is much higher than those experienced in roadside environments. Needless to mention that emission sources (e.g. tailpipe of vehicles) are closest to the roadsides and therefore already high PNCs are expected at such locations (Fujitani et al., 2012; Kumar et al., 2008). For the first time the above findings clearly highlight that workers at the refurbishment sites spend long hours and they are exposed to much higher PNCs than those experienced in outdoor ambient or micro-transport environments, indicating a clear need for limiting occupational exposure at such sites.

\section{SUMMARY AND CONCLUSIONS}

A DMS50 and GRIMM were used to measure number and size distributions of particles in the $5-10,000 \mathrm{~nm}$ size range released by numerous activities. While the DMS50 data was used to analyse the PNCs, the data measured from the GRIMM allowed us to assess PMCs in $\mathrm{PM}_{10}, \mathrm{PM}_{2.5}$ and $\mathrm{PM}_{1}$ fractions. Mass of bulk particles

Cite this article as: Azarmi, F., Kumar, P., Mulheron, M., Colauxc, J.L., Jeynes, C., Adhami, S., Watts, J.F., 2015. Physicochemical characteristics and occupational exposure to coarse, fine and nanoparticle emissions during building refurbishment activities, Journal of Nanoparticle Research 17, 343, doi: 10.1007/s11051-015-3141-z. Online link: $\underline{\text { http://dx.doi.org/10.1007/s11051-015-3141-z }}$ 
were also collected on the PTFE filters during background as well as activity periods for understand their physicochemical properties. The objectives were to understand the number and mass emission characteristics of particles in various size ranges during these building activities and assess their physical and chemical properties.

The following conclusions are drawn:

- The refurbishment activities were found to release ultrafine particles at levels well-above the local background PNCs. The UFPs were found to dominate (9197\%) the total PNCs. Average PNCs during the periods of refurbishment activities were found up to 84-times higher than the average PNCs during the background period. The largest PNCs were observed during the wall chasing activity, followed by the drilling and general demolition activities (SI Table S3).

- Results showed that highest mass concentrations of $\mathrm{PM}_{10}, \mathrm{PM}_{2.5}$ and $\mathrm{PM}_{1}$ (i.e. 20.01, 1.52, $0.18 \times 10^{2} \mu \mathrm{g} \mathrm{m}^{-3}$ ) were obtained during general demolition. The peak value of PMC was observed up to about 815-times higher over the background value during the drilling in comparison with the other activities. The mechanical attrition between the surfaces of instrument and materials during the activities and re-suspension of existing particles appears to be a likely source to produce larger-sized particles.

- Combining the results of XPS, SEM and IBA gives the capability of characterising both the micro- and nano-sized particles. The increase of the surface composition of new peaks and decrease of the $\mathrm{F}$ and $\mathrm{C}-\mathrm{F}$ peaks shows higher level of deposition of the particles on the filter and that the Fe-containing particles tend to form aggregates of few $10 \mu \mathrm{m}$. These analyses showed the presence of the elements such $\mathrm{Ca}, \mathrm{Si}, \mathrm{Cu}, \mathrm{K}, \mathrm{S}, \mathrm{Zn}$ and $\mathrm{Al}$ on the collected samples. These elements were presumably released from the building equipment and materials (e.g. concrete, bricks and metals) involved in the refurbishment activities.

- Occupations exposure to workers on the building refurbishment sites were found to contribute much higher exposure compared with typical roadside

Cite this article as: Azarmi, F., Kumar, P., Mulheron, M., Colauxc, J.L., Jeynes, C., Adhami, S., Watts, J.F., 2015. Physicochemical characteristics and occupational exposure to coarse, fine and nanoparticle emissions during building refurbishment activities, Journal of Nanoparticle Research 17, 343, doi: 10.1007/s11051-015-3141-z. Online link: http://dx.doi.org/10.1007/s11051-015-3141-z 
urban environments. Peak respiratory deposition doses during activity periods were over two orders of magnitude higher than those during the background periods, showing a broad diversity in the emission strengths of various refurbishment activities.

The study presented hitherto missing information that the refurbishment activities produce UFPs in dominant proportions. These high levels of UFP suggest that there is a need to design appropriate risk mitigation strategies to limit exposures of onsite workers. Dedicated studies are needed in future that can allow quantifying the PND signatures of individual refurbishment activities as well as the formation pathways of particles in the UFP size range.

\section{ACRONYMS}

UFP - Ultrafine particle

PM - Particulate matter

PND - Particle number distribution

PNC - Particle number concentration

PMC - Particle mass concentration

SEM - Scanning electron microscope

FIB - Focussed ion beam

PIXE - Particle induced x-ray emission

EBS - Elastic backscattering spectrometry

XPS - X ray Photoelectron Spectroscopy

IBA - Ion Beam Analysis

PTFE - Polytetrafluoroethylene

ICRP - International commission on radiological protection

VE - Tidal volume

DF - Deposited fraction

$f$ - Typical breathing frequency

MLD - Minimum level of detection

Cite this article as: Azarmi, F., Kumar, P., Mulheron, M., Colauxc, J.L., Jeynes, C., Adhami, S., Watts, J.F., 2015. Physicochemical characteristics and occupational exposure to coarse, fine and nanoparticle emissions during building refurbishment activities, Journal of Nanoparticle Research 17, 343, doi: 10.1007/s11051-015-3141-z. Online link: http://dx.doi.org/10.1007/s11051-015-3141-z 


\section{ACKNOWLEDGEMENTS}

The authors thank the University of the Surrey and Cara for supporting this work. Thanks also to Chris Burt, Anju Goel, Abdullah N. Al-Dabbous, Sujit Gurung and Dr Sanjay Mukherjee for their help during the experimental work.

\section{ASSOCIATED CONTENT}

Supporting Information (SI) includes Sections S1-S3, Tables S1-S5, and

Figures S1-S2.

\section{REFERENCES}

Adachi, K., Tainosho, Y., 2004. Characterization of heavy metal particles embedded in tire dust. Environment International 30, 1009-1017.

Adhami, S., Abel, M.L., Lowe, C., Watts, J.F., 2012. Failure of a waterborne primer applied to zinc coated steel. Surface and Interface Analysis 44, 1054-1058.

Adhami, S., Abel, M.L., Lowe, C., Watts, J.F., 2014. The role of the adhesion promoter in a model water-borne primer. Surface and Interface Analysis 46, 1005-1008.

Al-Dabbous, A.N., Kumar, P., 2014a. The influence of roadside vegetation barriers on airborne nanoparticles and pedestrians exposure under varying wind conditions. Atmos. Environ. 90, 113-124.

Al-Dabbous, A.N., Kumar, P., 2014b. Number size distribution of airborne nanoparticles during summertime in Kuwait: first observations from the middle east. Environmental Science \& Technology 48, 13634-13643.

Azarmi, F., Kumar, P., Mulheron, M., 2014. The exposure to coarse, fine and ultrafine particle emissions from concrete mixing, drilling and cutting activities. Journal of Hazardous Materials 279, 268-279.

Barradas, N., Jeynes, C., 2008. Advanced physics and algorithms in the IBA DataFurnace. Nuclear Instruments and Methods in Physics Research Section B: Beam Interactions with Materials and Atoms 266, 1875-1879.

Batonneau, Y., Bremard, C., Gengembre, L., Laureyns, J., Le Maguer, A., Le Maguer, D., Perdrix, E., Sobanska, S., 2004. Speciation of PM10 Sources of airborne nonferrous metals within the 3-km Zone of Lead/Zinc smelters. Environmental Science \& Technology 38, 5281-5289.

Beck, C.M., Geyh, A., Srinivasan, A., Breysse, P.N., Eggleston, P.A., Buckley, T.J., 2003. The impact of a building implosion on airborne particulate matter in an urban

Cite this article as: Azarmi, F., Kumar, P., Mulheron, M., Colauxc, J.L., Jeynes, C., Adhami, S., Watts, J.F., 2015. Physicochemical characteristics and occupational exposure to coarse, fine and nanoparticle emissions during building refurbishment activities, Journal of Nanoparticle Research 17, 343, doi: 10.1007/s11051-015-3141-z. Online link: http://dx.doi.org/10.1007/s11051-015-3141-z 
community. Journal of the Air \& Waste Management Association 53, 12561264.

Burt, S., Eden, P., 2004. The August 2003 heatwave in the United Kingdom. Part 2 the hottest sites. Weather 59, 239e246.

Carpentieri, M., Kumar, P., 2011. Ground-fixed and on-board measurements of nanoparticles in the wake of a moving vehicle. Atmospheric Environment 45, 5837-5852.

Chaloulakou, A., Kassomenos, P., Spyrellis, N., Demokritou, P., Koutrakis, P., 2003. Measurements of PM10 and PM2.5 particle concentrations in Athens, Greece. Atmospheric Environment 37, 649-660.

Chalupa, D.C., Morrow, P.E., Oberdörster, G., Utell, M.J., Frampton, M.W., 2004. Ultrafine particle deposition in subjects with asthma. Environmental Health Perspectives 112, 879 .

Chen, M., Wang, X., Yu, Y., Pei, Z., Bai, X., Sun, C., Huang, R., Wen, L., 2000. X-ray photoelectron spectroscopy and auger electron spectroscopy studies of Aldoped ZnO films. Applied Surface Science 158, 134-140.

Cohen, D.D., Bailey, G.M., Kondepudi, R., 1996. Elemental analysis by PIXE and other IBA techniques and their application to source fingerprinting of atmospheric fine particle pollution. Nuclear Instruments and Methods in Physics Research Section B: Beam Interactions with Materials and Atoms 109, 218-226.

Conny, J.M., 2013. Internal Composition of Atmospheric Dust Particles from Focused Ion-Beam Scanning Electron Microscopy. Environmental Science \& Technology $47,8575-8581$.

Dall'Osto, M., Thorpe, A., Beddows, D.C.S., Harrison, R.M., Barlow, J.F., Dunbar, T., Williams, P.I., Coe, H., 2011. Remarkable dynamics of nanoparticles in the urban atmosphere. Atmospheric Chemistry and Physics 11, 6623-6637.

Davila, A.F., Rey, D., Mohamed, K., Rubio, B., Guerra, A.P., 2006. Mapping the sources of urban dust in a coastal environment by measuring magnetic parameters of Platanus hispanica leaves. Environmental Science \& Technology 40, 39223928.

Directive, C., 1999. Council Directive 1999/30/EC of 22 April 1999 relating to limit values for sulphur dioxide, nitrogen dioxide and oxides of nitrogen, particulate matter and lead in ambient air. Journal of the European Communities 50, 4160.

Dorevitch, S., Demirtas, H., Perksy, V.W., Erdal, S., Conroy, L., Schoonover, T., Scheff, P.A., 2006. Demolition of high-rise public housing increases particulate matter

Cite this article as: Azarmi, F., Kumar, P., Mulheron, M., Colauxc, J.L., Jeynes, C., Adhami, S., Watts, J.F., 2015. Physicochemical characteristics and occupational exposure to coarse, fine and nanoparticle emissions during building refurbishment activities, Journal of Nanoparticle Research 17, 343, doi: 10.1007/s1 1051-015-3141-z. Online link: http://dx.doi.org/10.1007/s11051-015-3141-z 
air pollution in communities of high-risk asthmatics. Journal of the Air \& Waste Management Association 56, 1022-1032.

Egbu, C.O., 1999. Skills, knowledge and competencies for managing construction refurbishment works. Construction Management and Economics 17, 29-43.

Fujitani, Y., Kumar, P., Tamura, K., Fushimi, A., Hasegawa, S., Takahashi, K., Tanabe, K., Kobayashi, S., Hirano, S., 2012. Seasonal differences of the atmospheric particle size distribution in a metropolitan area in Japan. Science of the Total Environment 437, 339-347.

Fuller, G.W., Carslaw, D.C., Lodge, H.W., 2002. An empirical approach for the prediction of daily mean PM10 concentrations. Atmospheric Environment 36, 1431-1441.

Fuller, G.W., Green, D., 2004. The impact of local fugitive from building works and road works on the assessment of the European union limit value. Atmospheric Environment 38, 4993-5002.

Goel, A., Kumar, P., 2015. Characterisation of nanoparticle emissions and exposure at traffic intersections through fast-response mobile and sequential measurements. Atmospheric Environment., DOI: http://dx.doi.org/10.1016/j.atmosenv.2015.02.002.

Gomez, V., Levin, M., Saber, A.T., Irusta, S., Dal Maso, M., Hanoi, R., Santamaria, J., Jensen, K.A., Wallin, H., Koponen, I.K., 2014. Comparison of Dust Release from Epoxy and Paint Nanocomposites and Conventional Products during Sanding and Sawing. Annals of Occupational Hygiene. doi: 10.1093/annhyg/meu046

Goyal, R., Kumar, P., 2013. Indoor-outdoor concentrations of particulate matter in nine microenvironments of a mix-use commercial building in megacity Delhi. Air Quality, Atmosphere and Health 6, 747-757.

Goel, A., Kumar, P., 2015. Characterisation of nanoparticle emissions and exposure at traffic intersections through fast-response mobile and sequential measurements. Atmospheric Environment 107, 374-390.

Grimm, H., Eatough, D.J., 2009. Aerosol Measurement: The use of optical light scattering for the determination of particulate size distribution, and particulate mass, including the semi-volatile fraction. Journal of the Air and Waste Management Association 59, 101-107.

GroBmann, A., Hohmann, F., Wiebe, K., 2013. PortableDyme - A simplified software package for econometric model building. Macroeconomic Modelling For Policy Evaluation 120, 33.

Cite this article as: Azarmi, F., Kumar, P., Mulheron, M., Colauxc, J.L., Jeynes, C., Adhami, S., Watts, J.F., 2015. Physicochemical characteristics and occupational exposure to coarse, fine and nanoparticle emissions during building refurbishment activities, Journal of Nanoparticle Research 17, 343, doi: 10.1007/s11051-015-3141-z. Online link: http://dx.doi.org/10.1007/s11051-015-3141-z 
Hansen, D., Blahout, B., Benner, D., Popp, W., 2008. Environmental sampling of particulate matter and fungal spores during demolition of a building on a hospital area. Journal of Hospital Infection 70, 259-264.

He, C., Morawska, L., Hitchins, J., Gilbert, D., 2004. Contribution from indoor sources to particle number and mass concentrations in residential houses. Atmospheric Environment 38, 3405-3415.

Heal, M.R., Kumar, P., Harrison, R.M., 2012. Particles, air quality, policy and health. Chemical Society Reviews 41, 6606-6630.

HEI, 2013. HEI review panel on ultrafine particles. Understanding the health effects of ambient ultrafine particles. HEI Perspectives 3Health Effects Institute, Boston, MA (2013), p. 122 [http://pubs.healtheffects.org/getfile.php?u=893 (accessed 27 August 2014), 122.

Hinds, W.C., 1999. Aerosol Technology: properties, behaviour and measurement of airborne particles. John Wiley \& Sons, New York.

Hofmann, W., 2011. Modelling inhaled particle deposition in the human lung $\mathrm{d}$ a review. Journal of Aerosol Science 42, 693-724.

Hopke, P.K., Lamb, R.E., Natusch, D.F.S., 1980. Multielemental characterization of urban roadway dust. Environmental Science \& Technology 14, 164-172.

Hunt, A., Johnson, D.L., Watt, J.M., Thornton, I., 1992. Characterizing the sources of particulate lead in house dust by automated scanning electron microscopy. Environmental Science \& Technology 26, 1513-1523.

ICRP, 1994. Human respiratory tract model for radiological protection, a report of a task group of the international commission on radiological protection. ICRP Publication 66, 1-482.

Int Panis, L., de Geus, B., Vandenbulcke, G., Willems, H., Degraeuwe, B., Bleux, N., Mishra, V., Thomas, I., Meeusen, R., 2010. Exposure to particulate matter in traffic: A comparison of cyclists and car passengers. Atmos. Environ. 44, 2263 2270.

Jeynes, C., Bailey, M., Bright, N., Christopher, M., Grime, G., Jones, B., Palitsin, V., Webb, R., 2012. “Total IBA"-Where are we? Nuclear Instruments and Methods in Physics Research Section B: Beam Interactions with Materials and Atoms 271, 107-118.

Joodatnia, P., Kumar, P., Robins, A., 2013a. The behaviour of traffic produced nanoparticles in a car cabin and resulting exposure rates. Atmos. Environ. 65, 40-51.

Cite this article as: Azarmi, F., Kumar, P., Mulheron, M., Colauxc, J.L., Jeynes, C., Adhami, S., Watts, J.F., 2015. Physicochemical characteristics and occupational exposure to coarse, fine and nanoparticle emissions during building refurbishment activities, Journal of Nanoparticle Research 17, 343, doi: 10.1007/s11051-015-3141-z. Online link: http://dx.doi.org/10.1007/s11051-015-3141-z 
Joodatnia, P., Kumar, P., Robins, A., 2013b. Fast response sequential measurements and modelling of nanoparticles inside and outside a car cabin. Atmos. Environ. 71, 364-375.

Kohler, N., Hassler, U., 2002. The building stock as a research object. Building Research \& Information 30, 226-236.

Kulmala, M., Vehkamaki, H., Petaja, T., Dal Maso, M., Lauri, A., Kerminen, V.-M., Birmili, W., McMurry, P.H., 2004. Formation and growth rates of ultrafine atmospheric particles: a review of observations. Journal of Aerosol Science 35, 143-176.

Kumar, P., Fennell, P., Britter, R., 2008. Effect of wind direction and speed on the dispersion of nucleation and accumulation mode particles in an urban street canyon. Sci. Total Environ. 402, 82-94.

Kumar, P., Robins, A., Vardoulakis, S., Britter, R., 2010. A review of the characteristics of nanoparticles in the urban atmosphere and the prospects for developing regulatory controls. Atmospheric Environment 44, 5035-5052.

Kumar, P., Ketzel, M., Vardoulakis, S., Pirjola, L., Britter, R., 2011a. Dynamics and dispersion modelling of nanoparticles from road traffic in the urban atmospheric environment-A review. Journal of Aerosol Science 42, 580-603.

Kumar, P., Robins, A., Vardoulakis, S., Quincey, P., 2011b. Technical challenges in tackling regulatory concerns for urban atmospheric nanoparticles. Particulogy 9, 566-571.

Kumar, P., Azarmi, F., Mulheron, M., 2012a. Enlightening and noxious shades of nanotechnology application in concrete. Nanotechnology: Volume 7 Civil / Construction Engineering. (Studium Press LLC, USA; Govil, J.N. Eds.). ISBN: 162699-009-3. pp. 255-287.

Kumar, P., Mulheron, M., Fisher, B., Harrison, R.M., 2012b. New Directions: Airborne ultrafine particle dust from building activities - A source in need of quantification. Atmospheric Environment 56, 262-264.

Kumar, P., Mulheron, M., Som, C., 2012c. Release of ultrafine particles from three simulated building processes. Journal of Nanoparticle Research 14, 1-14.

Kumar, P., Jain, S., Gurjar, B.R., Sharma, P., Khare, M., Morawska, L., Britter, R., 2013a. Can a "Blue Sky" return to Indian megacities? Atmospheric Environment 71, 198-201.

Kumar, P., Pirjola, L., Ketzel, M., Harrison, R.M., 2013b. Nanoparticle emissions from 11 non-vehicle exhaust sources - A review. Atmospheric Environment 67, 252277.

Cite this article as: Azarmi, F., Kumar, P., Mulheron, M., Colauxc, J.L., Jeynes, C., Adhami, S., Watts, J.F., 2015. Physicochemical characteristics and occupational exposure to coarse, fine and nanoparticle emissions during building refurbishment activities, Journal of Nanoparticle Research 17, 343, doi: 10.1007/s11051-015-3141-z. Online link: http://dx.doi.org/10.1007/s11051-015-3141-z 
Kumar, P., Morawska, L., 2014. Recycling Concrete: an undiscovered source of ultrafine particles. Atmospheric Environment 90, 51-58.

Kumar, P., Morawska, L., Birmili, W., Paasonen, P., Hu, M., Kulmala, M., Harrison, R.M., Norford, L., Britter, R., 2014. Ultrafine particles in cities. Environment International 66, 1-10.

Lim, S.S., Vos, T., Flaxman, A.D., Danaei, G., Shibuya, K., et al., 2012. A comparative risk assessment of burden of disease and injury attributable to 67 risk factors and risk factor clusters in 21 regions, 1990-2010: a systematic analysis for the Global Burden of Disease Study 2010. Lancet 380, 2224-2260.

McKendry, I.G., van der Kamp, D., Strawbridge, K.B., Christen, A., Crawford, B., 2009. Simultaneous observations of boundary-layer aerosol layers with CL31 ceilometer and 1064/532 nm lidar. Atmospheric Environment 43, 5847-5852.

Mickaityte, A., Zavadskas, E.K., Kaklauskas, A., Tupenaite, L., 2008. The concept model of sustainable buildings refurbishment. International Journal of Strategic Property Management 12, 53-68.

Mouzourides, P., Kumar, P., Marina Neophytou, K.A., 2015. Assessment of long-term measurements of particulate matter and gaseous pollutants in South-East Mediterranean. Atmospheric Environment. DOI: http://dx.doi.org/10.1016/j.atmosenv.2015.02.031 107, 148-165.

Omer, A.M., 2008. Renewable building energy systems and passive human comfort solutions. Renewable and Sustainable Energy Reviews 12, 1562-1587.

Pacca, S., Horvath, A., 2002. Greenhouse gas emissions from building and operating electric power plants in the upper Colorado river Basin. Environmental Science \& Technology 36, 3194-3200.

Pattanaik, S., Huggins, F.E., Huffman, G.P., 2012. Chemical speciation of Fe and Ni in residual Oil Fly Ash fine particulate matter using X-ray absorption spectroscopy. Environmental Science \& Technology 46, 12927-12935.

Potgieter-Vermaak, S.S., Godoi, R.H.M., Grieken, R.V., Potgieter, J.H., Oujja, M., Castillejo, M., 2005. Micro-structural characterization of black crust and laser cleaning of building stones by micro-Raman and SEM techniques. Spectrochimica Acta Part A: Molecular and Biomolecular Spectroscopy 61, 2460-2467.

Raki, L., Beaudoin, J., Alizadeh, R., Makar, J., Sato, T., 2010. Cement and concrete nanoscience and nanotechnology. Materials 3, 918-942.

Cite this article as: Azarmi, F., Kumar, P., Mulheron, M., Colauxc, J.L., Jeynes, C., Adhami, S., Watts, J.F., 2015. Physicochemical characteristics and occupational exposure to coarse, fine and nanoparticle emissions during building refurbishment activities, Journal of Nanoparticle Research 17, 343, doi: 10.1007/s11051-015-3141-z. Online link: http://dx.doi.org/10.1007/s11051-015-3141-z 
Sartori, I., Bergsdal, H., Müller, D.B., Brattebø, H., 2008. Towards modelling of construction, renovation and demolition activities: Norway's dwelling stock, 1900-2100. Building Research \& Information 36, 412-425.

Sunikka, M., Boon, C., 2003. Environmental policies and efforts in social housing: the Netherlands. Building Research \& Information 31, 1-12.

Walker, S., Jamieson, H., Rasmussen, P., 2011. Application of synchrotron microprobe methods to solid-phase speciation of metals and metalloids in house dust. Environmental Science \& Technology 45, 8233-8240.

Watt, I.M., 1997. The principles and practice of electron microscopy. Cambridge University Press. Second edition. pp. 484.

Watts, J.F., Wolstenholme, J., 2003. An introduction to surface analysis by XPS and AES. An Introduction to Surface Analysis by XPS and AES, by John F. Watts, John Wolstenholme, pp. 224. ISBN 0-470-84713-1. Wiley-VCH, May 2003. 1.

Cite this article as: Azarmi, F., Kumar, P., Mulheron, M., Colauxc, J.L., Jeynes, C., Adhami, S., Watts, J.F., 2015. Physicochemical characteristics and occupational exposure to coarse, fine and nanoparticle emissions during building refurbishment activities, Journal of Nanoparticle Research 17, 343, doi: 10.1007/s11051-015-3141-z. Online link: http://dx.doi.org/10.1007/s11051-015-3141-z 